\title{
FIFTY-FIVE YEARS AT THE ALBERTA BAR: GEORGE HOBSON STEER, Q.C.
}

\section{W. F. BOWKER* \\ I. INTRODUCTION'}

George Hobson Steer was born in Hamilton, Ontario. ${ }^{2} \mathrm{He}$ became a schoolteacher. Enrolling at Queen's University as an extra-mural student, he later was in residence there, obtaining the degree of Master of Arts in May, 1912. The next month he came to Edmonton and entered into articles with C.L. Freeman of the firm of Boyle, Parlee, Freeman, Abbott and Mustard. At that time the period of articles was three years for a student with a degree. After a year Steer's ${ }^{3}$ articles were transferred to C.H. Grant of Rutherford, Jamieson and Grant. The head of this firm had been the first premier of Alberta. On October 8,1915 Steer was admitted as a Barrister and Solicitor before Mr. Justice J.D. Hyndman and soon after his name was added to the firm.

From the time of admission he did counsel work. Near the end of World War I he joined the Tank Corps as an officer and was in England at the Armistice. Soon after returning he left the Rutherford firm and joined in practice with Col. C.Y. Weaver. Weaver was a prominent Conservative while Steer, though never active in politics, was a Liberal. At first they did not have any large clients but did look after some British investments and acted for a good number of veterans. When prohibition came to an end after a plebiscite in the fall of 1923, the Northwest Brewing Company retained Weaver and Steer as its solicitors. At this time they joined Wallace McDonald, a senior practitioner, who acted for two lending institutions and had a good mortgage practice.

The firm of McDonald Weaver and Steer came to an end when McDonald died in 1929 and Weaver in 1930. This was the year in which Steer was appointed King's Counsel. In 1931 his name appeared in the firm of Steer, Jackson and Gaunt, though the writer's impression is that Roy Jackson really had an independent practice and that John Gaunt was an employee of Steer. For a short time in 1932 and 1933 the name of J.A. Matheson was on the letterhead. Near the end of 1933 Steer considered joining S.C.S. Kerr and the firm of Dyde and Becker, but before any arrangement was concluded H.R. Milner invited Steer to join his firm. Milner had come from Nova Scotia in 1912 to join Hyndman and Hyndman, and rose quickly at the bar. However, in 1932 he became president of

* Professor Emeritus and former Dean of the Faculty of Law, University of Alberta.

1. The writer acknowledges with thanks the helpful comments on an earlier draft by Mr. Justice Ronald Martland and by W.H. Hurlburt Q.C.; and the help of Prof. Maurice Sychuk Q.C. on the oil and gas cases; and that of W.B. Kelly Q.C., Secretary, Law Society of Alberta and of James Steer in reply to various inquiries; and the work done by F.P. Layton, then a law student, in the summer of 1975 in collecting Mr. Steer's cases. This last was made possible by a grant to the writer from the Alberta Law Foundation.

2. The Milner and Steer letter head gives his birth date as $\mathbf{1 8 8 6}$.

3. This article refers to many Alberta lawyers and a number from other provinces. Nearly every one was, or became, a King's Counsel or Queen's Counsel. It is with no disrespect to the many distinguished counsel that the writer omits the "K.C." and "Q.C.". He also omits "Mr.". The writer has difficulty in so doing because he always addressed, and still refers to many of the lawyers mentioned in this article as "Mister". 
Northwestern Utilities and its affiliated companies and so was seeking an able counsel. Steer agreed to join the Milner firm and moved to it in March 1934, the firm becoming Milner, Steer, Dafoe, Poirier and Martland." After a number of changes in the firm name, it became in later years simply Milner and Steer, as it now is. Steer retired in 1970. (The firm now has some forty-five names on the letterhead and an office in Calgary.)

In all his years of practice he did much solicitor's work as well as litigation. He never deviated from the general practice of law by taking important directorships or running for office. He was a hard worker, prompt and thorough, and single-minded in his attention to clients' affairs - and he expected others to be the same.

The writer makes no attempt to compare Steer with other leading counsel or to compute his record of wins and losses. He prepared evidence carefully and made effective use of expert witnesses. His legal research was thorough. In cross-examination he did not waste words but "went for the jugular", and though not colourful was forceful and effective. In legal argument he put his case clearly, succinctly and with force. He did not hesitate to advise against bringing or defending an action but once he had decided to litigate he was a fighter and did not easily give up. He was a careful and good convey ancer and knew the Rules of Court. When an issue in a matter of practice arose in the course of a case he did not hesitate to take it before the Chambers Judge or even the Appellate Division; ${ }^{5}$ and when he considered that a public official or body had refused to carry out a statutory duty, he was prepared to bring proceedings in mandamus. ${ }^{b}$

In his early years Steer was regarded as an equity and property lawyer, probably because he taught those subjects in the Faculty of Law at the University of Alberta. The fact is that he took every type of civil case and a number of criminal cases. He had many constitutional cases in the late thirties and forties and thereafter a large number of oil and gas actions, where his knowledge of equity and property law was put to use. Though often described as a specialist in property law, in constitutional law, in equity, or in oil and gas law, he was still a generalist.

One might gain the impression that he did nothing but work. It would be more accurate to say that he did not waste time. He followed sports closely. In his younger days he was a good tennis player. Later he took up badminton. In the thirties he would leave the Court House after a busy day, drive (with dispatch) to the Badminton Club and play (so the writer is told) with the same vigour he showed in his work. He was a good golfer though after the removal of an eye comparatively late in life played little. During World War II he took up skiing. For years he lunched at the Edmonton Club where he occasionally played poker. He was not particularly interested in travel and indeed did not spend much time on

4. John R. Gaunt and the writer went with Steer to the Milner firm.

5. On disputes over the right to discovery see Gille spie Grain v. Wacowich [1932]1 W.W.R. 916 (App. Div.); Northwestern Utilities v. Century Indemnity Co. [1934] 3 W.W.R. 139; Reese v. The Queen [1955] Ex. C.R. 187; Canadian Utilities L td. v. Mannix L td. (1959) 29 W.W.R. 289 (App. Div.).

6. R. v. Kamak (1920) 15 Alta. L.R. 373 (App. Div.); Re G(1922) 17 Alta. L.R. 473 (App. Div.); R. v.M.D. of Pembina (1922) 19 Alta. L.R. 9 (App. Div.).

7. When the directors of a Saskatchewan oil company wanted a "completely independent legal opinion" as to whether a proposed agreement was oppressive of minority shareholders, they went to Steer; see Farmers'Mutual Oil Co. v. U.S. Smelting Co. (1961) 34 W.W.R. 646 at 651 (Sask. C.A.). 
holidays. However, he did enjoy his cottage on Lake Edith in Jasper National Park.

His first wife (née Helen Cameron) had died in childbirth when their only child, Cameron, was born on September 8,1919. Steer raised his son. At the beginning of World War II Cameron went overseas as a lieutenant of artillery and served throughout the Sicilian and Italian campaigns. Wounded twice, he attained the rank of major. Returning home in 1946 with his war bride, Cameron spent the next five years at University and won the Gold Medal in law on graduation in 1951. He was articled to his father and in later years frequently appeared with him in court. Steer concealed his feelings but it is certain he was moved on the occasion when he presented his son to his old friend Mr. Justice Frank Ford on Cameron's admission to the bar in May, 1952, and again when Cameron was appointed as a judge of the Trial Division of the Supreme Court of Alberta in December 1974, six months before Steer's death. Cameron died from a sudden illness in December, $1979 .^{8}$

In June, 1938, Steer was married to a long time friend, Mrs. Irma May. She survived him by almost four years. A fine person, of remarkable disposition and a gracious hostess, she was an ideal wife.

\section{CASES OF THE EARLY YEARS}

In describing Steer's cases, the writer will try to maintain a chronological order and at the same time to group them by subject matter. In several instances there will be a compromise.

Steer's first reported appearance in court came within six months of admission to the bar. He acted for two homesteaders near Lake Wabamun. They owned a team of oxen and a cow. The tethered ox broke loose and the other animals followed. They were all struck by a train of the Grand Trunk Pacific Railway. Judge J.L. Crawford awarded the plaintiffs $\$ 225$. Neil D. Maclean, another young lawyer from Ontario who was to have a distinguished career as counsel, appeared for the Railway on its appeal. McLean's argument, that the animals were at large through the fault of the owners, failed. ${ }^{9}$

Six other reported cases in this period had to do with claims of priority as between creditors and claims of fraudulent preference. ${ }^{10} \mathrm{He}$ won the first two and lost the next four of these cases.

Steer's most significant case at this time was Consolidated Investments Ltd. v. Acres. " There had been a dramatic land boom in Edmonton, as elsewhere on the prairies, around 1910. It collapsed just before World War I. On a rising market buyers naturally want to enforce the agreement for sale and vendors are tempted to try to escape it. On a falling market the situation is reversed. Much of our law governing agreements for sale of land and dispostion of mineral rights has been established in this context. In Acres, the plaintiff's president had gone to Toronto in 1912 and sold a large number of lots on the western outskirts of

8. Cameron's wife had predeceased him in 1962. He left surviving four children.

9. Waite \& Walker v. Grand Trunk Pacific Railway (1916) 11 Alta. L.R. 260 (App. Div.).

10. MacKinnon v. Horn (1916) 10 Alta. L.R. 389 (App. Div.); Re City Transfer Co. (1917) 11 Alta. L.R. 83 (App.. Div.);Re Extra-judicial Seizures Act (1917) 12 Alta. L.R. 141; Tropox v.Droney (1918) 13 Alta. L.R. 39 (App. Div.); Clarke v. Sutherland (1917) 13 Alta. L.R. 132 (App. Div.); Sutherland v. Clarke (1917) 13 Alta. L.R. 330 (App. Div.).

11. (1917) 12 Alta. L.R. 210 (App. Div.). 
Edmonton. He painted a glowing picture to Mr. Acres. One of his representations was that the land was within a four-mile circle of the Edmonton post office. It was in fact a half-mile further away. Two years later the vendor brought the usual action for specific performance. Steer for the defendant argued that his client had rescinded the agreement for misrepresentation and also that the plaintiff did not have title to the land. He lost at trial but on appeal the Court held that there was misrepresentation and that the rescission was effective.

Steer's reported cases in the early twenties are not especially noteworthy. He acted for a company whose controlling shareholder, as the Court found, improperly used funds of another company to buy property $;^{\prime 2}$ he lost an action for specific performance because the Statute of Frauds was a good defence; ${ }^{13}$ and he successfully defended an action for rescission ${ }^{14}$ and one alleging a fraudulent preference. ${ }^{15}$

In the same period the Law Society of Alberta used Steer as its solicitor in disciplinary proceedings. Until 1921 disbarment for unprofessional conduct was in the hands of the Court, not the Benchers. ${ }^{16}$ In one case where the lawyer's main offence was in ignoring the Law Society's letters, Walsh J. declined to disbar him but ordered him to pay the costs, while commenting that "Mr. Steer's attitude had been most commendable." 17 When the Benchers in 1921 were given power to strike off the rolls, an appeal lay to the Appellate Division, as it still does to the Court of Appeal. On two applications for reinstatement in 1924 the Court found no adequate evidence of rehabilitation, though Beck J.A. would have reinstated the applicants under strict conditions. ${ }^{18}$

Steer's first appearance before the Supreme Court of Canada came in 1926 on behalf of the plaintiff in Standard Trust Company v. Hiram M.D. The action was to set aside a tax sale because the municipality had not given to the plaintiff (a mortgagee) notice of the sale and of its right to redeem. The question was whether the wide curative section in the Act covered failure to give notice. Mr. Justice John Boyle, at trial, answered in the negative. Thus the plaintiff won, but the Appellate Division reversed the trial judge. On the plaintiff's appeal to the Supreme Court the trial judgment was restored. Failure to give notice was so fundamental that it rendered the proceedings ineffectual. ${ }^{19}$

Steer had a small number of matrimonial cases. In 1924, there was no Domestic Relations Act and considerable doubt as to the law on alimony. Nevertheless, Steer succeeded in an action for alimony. Two judges held that an earlier separation agreement had not negatived the duty to support, two found a resumption of cohabitation which brought the agreement to an end, while Beck J.A., expressing uncertainty as to the law of

12. Northern Creameries v. Rossington Produce Co. (1922) 17 Alta. L.R. 478 (App. Div.).

13. Mandziuk v. Czahley (1920) 16 Alta. L.R. 68 (App. Div.).

14. Haste v. Goodman (1922) 18 Alta. L.R. 15 (App. Div.).

15. Banque d'Hochelaga v. Potvin (1924) 20 Alta. L.R. 121 (App. Div.).

16. Legal Profession Act, S.A. 1907 c. 20 s. 52, as am. S.A. 1921 c. 5 s. 7.

17. $\operatorname{Re} X(1920) 16$ Alta. L.R. 542.

18. Re V(1924) 20 Alta. L.R. 585 (App. Div.); $R e E$ (1924) 20 Alta. L.R. 597 (App. Div.). The Court's power to reinstate, given by section 56 , was not affected by the 1921 amendment.

19. [1927] S.C.R. 50, revg. (1926) 22 Alta. L.R.148 (App. Div.). In Standard Trust Company v. Stewart M.D. (1929) 24 Alta. L.R. 56 (A pp. Div.) Steer failed in an action to redeem lands after an agreement for sale had been made in tax sale proceedings. 
Alberta, simply concurred..$^{20}$

In another case Steer acted for a woman who claimed veteran's insurance on the death of the man with whom she had been living. The Crown denied she was the lawful wife. However the Exchequer Court held cohabitation created a sufficient presumption of marriage and that the Crown had not rebutted the presumption. On the Crown's appeal to the Supreme Court of Canada, Steer was represented by eastern counsel when the appeal was dismissed. ${ }^{21}$

In 1931 a divorced wife brought action to set aside a divorce, the former husband having died in the meantime. Neil Maclean acted for the plaintiff and Steer for the defendant. Each had recently been made King's Counsel. Steer applied for an order striking out the statement of claim, arguing that the divorce was a judgment in rem and was not subject to attack after the husband's death even though the plaintiff alleged fraud. Tweedie J., in one of his rare long judgments, rejected this argument and a divided Appellate Division upheld him. ${ }^{22}$ The case never went to trial. ${ }^{23}$

Motor vehicle cases, like those in family law, were not frequent. In the days before we had a Contributory Negligence Act, Steer once acted for the plaintiffs whose car collided with a street car at an intersection. The action failed except for the passengers' claims. ${ }^{24}$ Later he acted for passengers in a taxi who sued both the taxi company and the other party to a collision. At that time courts were tempted to identify passengers with their driver's negligence and to allow recovery only against the driver who had the last clear chance. In this case S.B. Woods, a leading counsel of the day, vigorously argued that his client (the other party) was not liable. He failed and on his appeal the court did not call on Steer. ${ }^{25}$

The most important vehicle case was Jeremy v. Fontaine in 1931. Since a plaintiff failed completely if he were guilty of contributory negligence, the courts developed the doctrine of last clear chance to render the defendant liable. In this case Steer acted for a plaintiff who stepped out onto the St. Albert Trail from behind a parked car. The defendant driving along the trail struck the plaintiff. Although the latter was contributorily negligent, Ford J. found that the defendant's brakes were faulty and that had they been sound he could have avoided the accident. In the language of the day he would have had the last clear chance but for his prior incapacitating negligence. The defendant's appeal was dismissed.$^{26}$ Today, of course, the plaintiff's damages would be apportioned under the Contributory Negligence Act.

The last important vehicle case, George v. Brown and Imperial Oil ${ }^{27}$, a decade later, can be noted here. Brown worked as a salesman and supervisor for Imperial Oil Co. He lived in Edmonton but his work was in the

20. Christofferson v. Christofferson (1924) 21 Alta. L.R. 13 (App. Div.).

21. Proud v. The King [1926] Ex. C.R. 1; affd. sub nom The King v. Proud [1926] S.C.R. 509.

22. Blatchford v. Van Ruyven (1931) 25 Alta. L.R. 404 (App. Div.).

23. Frank Ford J. so stated in McPherson v. McPherson (No. 2)[1933] 2 W.W.R. 513. Later cases show that a person attempting to set aside a divorce has a hard task: Bukowicki v. Bukowicki [1945] 3 W.W.R. 402; however the action has sometimes succeeded e.g. in Rivas v. Rivas [1977] 2 W.W.R. 345.

24. Weaver v. Edmonton [1923] 3 W.W.R. 682 (App. Div.).

25. Macdonnell v. Pech (1930) 25 Alta. L.R. 129 (App. Div.).

26. Jeremy v. Fontaine (1931) 26 Alta. L.R. 499 (App. Div.); affg. [1931] 1 W.W.R. 671.

27. [1940] 2 W.W.R. 65 (App. Div.). 
Camrose area. On his way back to the city in his own car he struck George's car. George sued Brown and also Imperial as the employer. The trial was by judge and jury, which even in 1940 was becoming a rarity in civil cases in Alberta. The jury found Brown negligent. The judge had instructed them that if they found Imperial had the right to control Brown on his way to and from Camrose they should find Imperial liable. This the jury did. Steer appeared for Imperial on the appeal and succeeded in obtaining an order for a new trial on the ground that the direction was inaccurate as to the basis of the master's liability for the servant's negligence. The writer's recollection is that the second trial never took place.

In the field of real property law, the number of cases in the twenties and thirties was not large. In one important case in 1923, Andrews v. Sinclair, ${ }^{28}$ Sinclair in Australia gave to Griffith of Edmonton a power of attorney to deal with Sinclair's Canadian assets. The instrument said that Sinclair wanted to give Griffith such powers as were needed to dispose of property "with the same powers and authorities in all respects as if I were personally present". No specific power to mortgage land was included, though there were specific powers to lease and sell. The question was this: did Griffith have power to mortgage the lands? Steer argued that he did, but the Appellate Division held that the power to give a mortgage would have to be explicit and could not be inferred from the instrument. Had Sinclair used the form set out in the Land Titles Act, he would have been reminded to specify the power to grant a mortgage had he wished to confer it.

McLeod v. Pearson ${ }^{29}$ in 1931, dealt with another important problem in land law. It had to do with the time limit for suing on a mortgage debt, and on suing for foreclosure. Alberta did not have a comprehensive Limitations Act until 1935. Prior to that we had a short statute which had come down from territorial days. It declared that the English Real Property Limitations Act, 1874, was in force. Steer acted for a mortgagor who brought action for a declaration that the mortgage was no longer a charge on the land because the mortgagee had not brought action within 12 years after the right so to do had arisen. S. Bruce Smith, who was to become a leader at the bar and later Chief Justice of Alberta, appeared for the mortgagee. The mortgagor or his agent had signed three letters, all of which acknowledged the debt and one of which had acknowledged the mortgagee's "title". Thus it would appear that the mortgage was still valid. However, the three letters had been written to the mortgagee's former solicitor after he had written to inquire as to whether the mortgagor was keeping up a prior mortgage. The letter from the former solicitor had been written "without prejudice". Frank Ford J. held that such a letter protects subsequent correspondence on the same subject matter, so the three letters from the plaintiff or his agent were also "without prejudice". Therefore they were inadmissible as an acknowledgement. In the result, Steer succeeded in having the mortgage removed from the title.

An unusual case on real property law is Canadian Mausoleums Ltd. v. Irwin ${ }^{30}$ The Edmonton Cemetery Company had agreed to buy lands from the Hudson's Bay Company and then in 1929 gave to Canadian Mausoleums Ltd. an option "for the perpetual right to use a plot of ground

28. (1923) 19 Alta. L.R. 463 (App. Div.).

29. [1931] 3 W.W.R. 4 .

30. [1933] 1 W.W.R. 405, affd. [1933] 3 W.W.R. 224 (App. Div.). 
in Edmonton Cemetery ... for the purpose of erecting a mausoleum thereon and of disposing of the compartments and private rooms in the same". Canadian Mausoleums took up the option and the mausoleum was largely completed by September, 1930. In the preceding month Irwin had purchased two compartments in the mausoleum for $\$ 950$. In December, 1931 , Steer wrote the Mausoleum company that his client repudiated the agreement on the ground that the company "has not a good title to the lands purported to be sold to our client". The company then sued for the purchase price. Mr. Justice Ford held that the agreement gave Irwin an interest in land, though he left open the question as to the nature of the interest. The company's only right in the land was the perpetual right to use it whereas the company had purported to give Irwin possession of the two crypts. This was a greater right than the company had to give. Moreover the Cemetery Company at the time of the repudiation did not have title to the land or the right to compel the Hudson's Bay Company to grant title. Thus Irwin was entitled to repudiate.

The company's appeal was dismissed without reasons and a further appeal to the Supreme Court of Canada was abandoned.

A real property case, Cristall v. T. Eaton Co. ${ }^{31}$ which came somewhat later, can be described here. In the fall of 1928 Eaton decided to buy land in downtown Edmonton for a store. Cristall owned desirable property. He gave an option to a real estate agency which was attempting to acquire land for Eaton. A condition of the option was that the property "is being purchased for use in connection with a department store site". Through a subsidiary, Eaton took up the option with the condition included. Eaton did not build immediately. Cristall alleged a verbal covenant to build and claimed $\$ 490,000$ for breach. G.W. Auxier, the solicitor for Eaton, retained Steer. On a conflict of evidence as to what was said during the negotiations, Ewing J. found a verbal undertaking that Eaton would within a reasonable time use the premises as a department store. However, he found no covenant to build, either written or verbal. Thus he did not have to deal with complicated questions of agency, the parol evidence rule, and the Statute of Frauds, all of which had been minutely examined by counsel on both sides. Not long after the trial, Eaton built on the property a store which it still operates.

The last case in this part has nothing to do with property. In 1931, when appeals still lay to the Privy Council, this question arose. Where a Privy Council judgment is in conflict with one of the House of Lords, which of them should an Alberta court follow? Since abolition of appeals to the Privy Council this question has become academic. However it was not academic in 1931. In Will v. Bank of Montreal ${ }^{32}$ gamblers lured Will into a poker game in Edmonton. One of them, King, filled in a cheque for $\$ 50.00$ for Will to sign to cover his loss. Will signed it. Later King, having left ample space for the purpose, raised the cheque to $\$ 1,150.00$ and through a devious route cashed it. Will brought action against his bank for damages for paying a raised cheque.

The Privy Council had said that a customer does not violate his duty of care towards his bank merely by drawing the cheque with spaces which a forger could utilize to raise the cheque ${ }^{33} \mathrm{~A}$ later House of Lords decision

31. [1937] 3 D.L.R. 700.

32. [1931] 2 W.W.R. 364.

33. Colonial Bank v. Marshall [1906] A.C. 559. 
said the customer owes his bank a duty to take reasonable precautions against forgery ${ }^{34} \mathrm{H}$.A. Friedman, another leader of the bar at the time, argued for the plaintiff that an Alberta court was bound to follow the Privy Council. Steer, who had been retained by the bank's solicitors, contended that the House of Lords' judgment was binding. Mr. Justice Frank Ford enjoyed a problem like this. He reviewed many cases. Specifically quoting and adopting Steer's argument, he concluded that the House of Lords "is the supreme tribunal to settle English law"35 so that he should follow it. Thus Will, having failed to take reasonable steps to guard against forgery, failed in his action. One might wonder why the plaintiff did not appeal. The writer has always understood that the Bank settled in full.

\section{ACTIONS AGAINST THE CITY OF EDMONTON}

In the period shortly before Steer joined the Milner firm, he acted for the plaintiff in each of three actions against the City. The first and most significant, Clarke v. Edmonton ${ }^{36}$ raised the question of riparian rights on the North Saskatchewan River, which is navigable and non-tidal.

In 1882 a number of large river lots were surveyed on both sides of the river at the Edmonton settlement. Lot 21 containing 163 acres was a quarter of a mile wide and a mile from North to South. The northern boundary was the south bank of the river. ${ }^{37}$ In 1924 Clarke obtained title to a comparatively small part of the lot between Dowler's Hill Road and the riverbank. In the preceding fourteen years, thanks to floods and changes in the current, a bench had grown up in the river bed adjacent to the South bank. It varied in depth from thirteen feet at the West to half that depth at the East. From North to South the bench varied in width, with a maximum of eighty feet. Beginning in 1920 the city had deposited refuse on a small area at the east end of the bench. Clarke claimed ownership of the bench by accretion, and in 1925 brought action for trespass. At that time, the original bank was still visible, but the bench had grown up with vegetation and a new bank had been formed at the North side of the bench.

Steer acted for Clarke and J.C.F. Bown, the City Solicitor, for the City. $\mathrm{Mr}$. Justice Tweedie held that Clarke did not acquire ownership of the bench by accretion and so dismissed the action. Clarke appealed. Because of the possibility that the Crown in right of Canada owned the bench, the Attorney General of Canada intervened, and was represented by H.H. Parlee, an eminent counsel. Three of the four judges in the result agreed with the trial judge. The original boundary was visible. Chief Justice Harvey added that the bench had not been formed slowly and imperceptibly by accretion, but rather had been formed by avulsion in a fourteen year period, so the riparian owner could not claim ownership. Mr. Justice Beck gave a lengthy dissent. He held there was a true accretion and that the bench belonged to Clarke. The judgments referred to the common law rule that a riparian owner owned to the middle of the stream, and con-

34. London Joint Stock Bank v. Macmillan [1918] A.C. 777.

35. Supra n. 32 at 375.

36. [1930] S.C.R. 137; revg. (1928) 23 Alta. L.R. 233 (App. Div.).

37. See map in MacGregor, $A$ History of Edmonton (2nd ed. 1975) at 96, 97. The footbridge across the river near the Muttart Conservatory is at lot 21, as best as the writer can determine. 
firmed an earlier Alberta decision that this rule did not apply in Alberta. ${ }^{36}$

Clarke appealed to the Supreme Court of Canada. Parlee now represented the City and Eugene Lafleur, the great Montreal advocate, appeared for the Attorney General of Canada. ${ }^{39}$ In a unanimous judgment in late 1929, the Supreme Court allowed the appeal, agreeing with Mr. Justice Beck, who had died before the appeal was heard. To decide whether Clarke became the owner, the court looked at the law of England as it existed on July 15,1870, which was the date when the law of England became the law of the Northwest Territories and hence of Alberta. In England an accretion to the shore of a non-tidal navigable river belonged to the riparian owner. This rule did not depend on the notion of ownership to the middle of the stream. The boundary of Clarke's lot was the river, not the old bank, visible though it was. ${ }^{40}$

This case did not end Clarke's litigation with the City. He lived on his land by the river. Not far away the City had a sewage disposal plant. Clarke brought an action in nuisance for an injunction and damages. Again Steer appeared for him, while G.B. O'Connor, another prominent lawyer and later Chief Justice of Alberta, was counsel for the City. Clarke's case was that the odours from the plant were so frequent and intense as materially to interfere with the enjoyment of his home. The evidence at the trial was conflicting. Ewing $J$. found the odours constituted a nuisance. The question then was whether he would give an injunction in view of the City's statutory authority to operate the plant. The judge held that the City was bound to maintain the plant. However he found that its method of operation was negligent so that its statutory authority did not protect it. He granted the injunction but gave the City time in which to abate the nuisance. The plant was never shut down. The City improved it so that the odours no longer constituted a nuisance."

Steer's last action against the City was Carmichael v. Edmonton. The Carmichaels, husband and wife, worked at the Edmonton Club (where Steer was a member). On 22nd December, 1931, Mrs. Carmichael slipped and fell on an icy sidewalk just north of the Club and sustained a broken leg. The City Charter required written notice within 10 days, although want of notice was not a bar if there were a reasonable excuse and no prejudice to the City in its defence. She did not consult Steer until long after the expiration of the 10 days. He sent notice of the accident on March 2, 1932. The City denied liability so the Carmichaels sued. Steer had to prove gross negligence as the City Charter required.

The plaintiff's witnesses testified that the icy patch had existed for a long time, while the street cleaning crew testified they had removed all snow and ice (by shovelling it from the sidewalk onto their horse-drawn sleighs) the day before the accident. Mr. Justice Ives accepted the plaintiff' evidence. He found gross negligence and on the question of failure to give timely notice he found reasonable excuse and no prejudice. The City appealed. The Appellate Division found prejudice so allowed the appeal. Steer appealed to the Supreme Court of Canada. He retained J.A. Ritchie, an Ottawa lawyer, to argue his case. The appeal failed. Through his

38. Clarke v. Edmonton (1928) 23 Alta. L.R. 233 (App. Div.).

39. This must have been one of his last cases, for he died in April, 1930.

40. Clarke v. Edmonton [1930] S.C.R. 137.

41. Clarke v. Edmonton [1933] 1 W.W.R. 113. 
London agents Steer applied to the Privy Council for leave to appeal but it was refused..$^{42}$

\section{FIRE CASES: HEREIN THE NORTHWESTERN UTILITIES (CORONA HOTEL) CASE}

Steer had a number of lawsuits arising from fires, covering a long time span. By a coincidence, in all of his fire cases Steer acted for the defendant. He invariably pleaded the Fires Prevention (Metropolis Act), $1774 .^{43}$ Section 86 of that Act said a person is not liable for damages from a fire which accidentally begins on his premises. It might seem odd that an eighteenth century statute dealing with fires in London could possibly be in effect in Alberta, but it is. ${ }^{44}$ However, the writer cannot discern that it affected the result in any of the cases about to be described.

Steer's first fire case was McDonald v. Onyschuk. ${ }^{45}$ At that time (1920) the Prairie Fires Ordinance ${ }^{46}$ was still in effect. It set out precautions to be taken to prevent fires from spreading. A person building a fire for the purpose of clearing land was obliged to have a fireguard and to have three adults with proper extinguishers to guard the fire. The defendant was breaking land. His daughter lit several small piles of roots. The fire spread across the road to two or three farms and then consumed the plaintiff's house. The trial judge held that the defendant was "clearing land" and as he had erected no fireguard, he was liable. On appeal Steer argued successfully that the defendant was not clearing land so the Ordinance did not apply. Our law was already settled that where a fire is made "for purposes of husbandry" the old common law rule of strict liability is replaced by liability for negligence, and a majority found no negligence.

In Gillespie Grain Co. v. Wacowich in 1932, the defendant was the plaintiff's agent at Opal. He kept the company's money in a shoe box on a shelf in his store. The building burned and the money was destroyed. Both the trial judge and the Appellate Division found Wacowich liable for the loss of the money. ${ }^{47}$

The fire that burned down the Corona Hotel in Edmonton on a cold February night in 1932 gave rise to a lawsuit in which London Guarantee Co. and ninety other plaintiffs sued Northwestern Utilities, a company which had provided gas in Edmonton since 1923." The company had an underground gas main in the east-west lane south of the hotel. The main broke at a weld where the main crossed a City street just west of the hotel. The weld had given way because the pipe had subsided. Gas from the broken main seeped underground until it entered the basement of the hotel. The janitor hearing a strange hiss lit a match to find the source. He escaped but the hotel was destroyed; hence the action against Northwestern. The plaintiffs alleged nuisance, both public and private,

42. [1933] S.C.R. 650 affg [1933] 1 W.W.R. 533 (App. Div.); see also [1934] S.C.R. vii.

43. 14 Geo. III c. 78.

44. Johnson v. Conrow [1951] 4 D.L.R. 493: Coté, "The Introduction of English Law into Alberta" (1964) 3 Alta. L. Rev. 262 at 286.

45. (1921) 17 Alta. L.R. 314 (App. Div.).

46. N.W.T. Ordinances in Force in Alberta, 1915 c. 87.

47. The judgments on the merits are unreported. This paragraph is from memory.

48. Northwestern Utilities v. London Guarantee Co. [1936] A.C. 108; affg. sub nom London Guarantee Co. v. Northwestern Utilities [1934] 3 W.W.R. 641 (A pp. Div.); revg. [1934] 1 W.W.R. 675. 
the doctrine of Rylands v. Fletcher, breach of statutory duty and negligence.

The case came on for trial before Frank Ford J. in January 1934 and lasted for 14 days. Out of the many issues, all vigorously fought, the plaintiff's main case was that the gas company was negligent in having laid the pipe without proper support beneath, so that it sagged and broke. The gas company's answer was that the reason for the subsidence and consequent rupture at the weld was the action of the City in excavating under the pipe while installing a storm sewer a year before the fire. For the plaintiffs, S.B. Woods was the leading counsel, along with five others. For the defendant were A.L. Smith, an excellent trial lawyer from Calgary, Milner, Ronald Martland, a young partner of Milner's (and from January, 1958 until retirement in February 1982, a judge of the Supreme Court of Canada), and S.C.S. Kerr. The last named represented the defendant's insurer.

The principal question of fact was the cause of the subsidence and break. Lengthy expert evidence was given on both sides and the crossexamination was skilful. The trial judge found as a fact that the City's excavation underneath the gas company's main was the cause of the subsidence and the break. In other words, he accepted the defendant's version of the cause, and rejected the plaintiffs'. The defendant was not negligent. However, near the end of his judgment, Mr. Justice Ford added, almost as an afterthought: ${ }^{49}$

... I think that the defendant ought to have known even if it did not, that the operations were going on, because of the length of time they were carried on and the conspicuous and public nature thereof. I think however that the defendant had the right to rely upon the City engineer ... seeing that the work was done in such a way that such result as has happened would not occur.

The plaintiffs appealed. Steer had joined the Milner firm two weeks after the judgment. He appeared on the appeal with Smith, Martland and Kerr. Woods and Friedman, for the appellants, argued strenuously but without success that the trial judge's finding of fact was wrong. They also argued that even if it were correct the plaintiffs should succeed because the gas company knew of the City's activity around the gas main and was under a duty to protect it. Three of the five judges accepted this argument so the appeal was allowed.

The defendant had the choice of appealing either to the Supreme Court or direct to the Privy Council. It took the latter course. Milner instructed his London solicitors, Charles Russell \& Co., to retain Wilfred Greene, K.C., an outstanding member of the English bar at the time. This was his last case. Before the Judicial Committee rendered its judgment he was appointed Lord Justice of Appeal. Later he became Master of the Rolls and then a Lord of Appeal in Ordinary. Steer appeared with him, while for the respondents W.N. Tilley of Toronto, a leading counsel, had with him Woods and an English barrister, Frank Gahan, who had a large Privy Council practice though not yet a King's Counsel.

The argument took five days in the latter part of July, 1935. On the Judicial Committee were the Lord Chancellor, Viscount Hailsham, (father of the present Lord Chancellor), Lord Blanesburgh and Lord Wright. The last named delivered the judgment which was handed down on October 24, 1935. 
The Judicial Committee absolved the defendant from liability under Rylands v. Fletcher because it came within two of the exceptions statutory authority and the independent act of a third party. However, the judgment concurred in the view of the majority in the Court of Appeal. Although the City's conduct caused the break, the defendant, in conveying a dangerous substance like gas through its pipes, was under a duty of care to the plaintiffs. ${ }^{50}$

If they did not know of the City works, their system of inspect ion must have been very deficient. If they did know they should have been on their guard.... Their dut y to the respondents was at the lowest to be on the watch and to be vigilant: they do not even pretend to have done as much as that.

Thus the plaintiffs won on a ground utterly different from that on which they had based their case. As Lord Wright said, the respondents "have failed on the issue which has bulked so largely, whether the breaking of the pipe was due to the fault of the City or of the appellants, and succeed on an issue not raised in the pleadings ...". "For this reason the appellant was required to pay only two-thirds of the respondents' costs.

This is an important case in the law of negligence. It is cited in all the leading texts on torts - Salmond, Winfield, Street, Prosser and Fleming. The late Dean Wright included it in his Cases on Torts and Lord Wright himself, the author of the judgment, once gave a lecture to Harvard Law School on the case. ${ }^{52}$

The amount of damages to which each of the many plaintiffs was entitled was left until after the Privy Council had determined the question of liability. The claims came to a total of some $\$ 300,000$. They raised many interesting questions in the law of damages in relation to property. What is the value of a profitable but obsolescent hotel? What is the value of a trinket to which great sentiment is attached? What is the value of a wellworn suit of clothes in a depression? The defendant settled all of the claims. However, two persons who had not joined in the principal action sued separately. It is interesting to speculate as to whether they would have had to prove their case all over again had the defendant denied liability. It is not at all clear that the issue would have been res judicata. However, the defendant did not take this course. It settled with one of the two. The remaining case went to trial solely on the question of damages. The plaintiff was a retired geologist who claimed $\$ 10,000$ for notes, reports and maps he had made almost 30 years before. $\mathrm{Mr}$. Justice Ewing awarded him $\$ 646 .{ }^{53}$

After the fire the gas company odorized its gas and in addition developed new techniques for detecting leaks in its pipes. Indeed it was not long before a situation arose in which the company had to heed Lord Wright's admonition to protect its pipes. The company had a main which carried the company's gas from its wells near Viking to Edmonton. The main ran under the highway right-of-way a few miles east of the city. A coal mining company planned to run tunnels across the highway and under the main. Mindful of the Corona case, the company was concerned about the possibility that the mining operations might cause the main to subside and possibly to break. The company asked the government to re-

50. [1936] A.C. 108 at 127 .

51. Id. at 128 .

52. Lord Wright of Durley, "The Northwestern Utilities Case" Legal Essays and Addresses (1939) 124.

53. Reade and George v. Northwestern Utilities [1938] 1 W.W.R. 647. 
quire the coal company to leave in place sufficient coal to eliminate any risk of subsidence. The coal company alleged that this would require it to leave in place 249,000 tons of coal. It brought action for a declaration that (1) the gas company had no right to require the plaintiff to leave any coal in place and in the alternative (2) that the defendant had no right to require the plaintiff to support the gas company's pipe without paying compensation. Martland appeared for the defendant on its application to strike out the statement of claim on the ground that a declaratory judgment should not be given simply to define the mutual rights of the parties, but only where the defendant had illegally threatened the plaintiff's rights, and that there had been no such threat here. Mr. Justice Ives held that the court had no jurisdiction to give a declaratory judgment in this case. The plaintiff merely wanted the opinion of the court; no right of the plaintiff had been illegally threatened, and no consequential relief could follow any of the declarations prayed for. On the plaintiff's appeal, Maclean and his partner E.W.S. Kane appeared for the appellant while Steer and Martland represented Northwestern. Mr. Justice McGillivray for the majority made a lengthy review of the cases on declaratory judgments and concluded that the court had jurisdiction to deal with the declarations sought by the plaintiff. The writer does not know what happened after this judgment. ${ }^{5 A}$

Steer's next fire case, Mudry v. Geary, attracted none of the interest that surrounded the Corona Hotel case. It occurred around 1936, as best the writer can recall, and is not even reported. The defendant was a bank manager in Leduc. Being about to move out of his house, he lit a fire in the lane to burn rubbish. His evidence was that he took stringent steps to put out the fire. A wind rose and sparks spread to the plaintiff's lumberyard, which was largely consumed. Steer succeeded in his argument that the plaintiff had not proved negligence. The writer always thought the defendant to be extremely fortunate.

The last fire case was City of Edmonton v. W.W. Sales Ltd. . ${ }^{54}$ Steer was counsel for the Friedman and Lieberman firm, who acted for the defendant. The defendant had used for storage the basement of the Sheldon Block not far from its store. On a January day in 1940 the manager instructed two employees to clean out the cellar. They did so and burned the rubbish in a steel ash-can in the lane. A wind came up and the fire spread to the nearby Powell Block owned by the City. Howson J. found the employees negligent in burning the rubbish in the lane near the buildings. On appeal, Steer's main argument was that the employees had no authority to burn the rubbish and that such authority could not be implied in the face of a by-law prohibiting such burning. The argument failed in the Appellate Division and again in the Supreme Court of Canada. From hindsight it might seem that the argument was hopeless from the beginning. It may be recalled however that the Ontario courts had accepted a similar argument in Lockhart v. C.P.R..$^{55}$ Unfortunately for Steer, the Supreme Court reversed the Ontario Court of Appeal before our Appellate Division's judgment in $W . W$. Sales ${ }^{56}$ and the Privy Council affirmed the

53A. Kent Coal Co. v. Northwestern Utilities [1936]2 W.W.R. 393. (App. Div.).

54. [1942] S.C.R. 467 affg. [1942] 1 W.W.R. 375 affg. [1941] 2 W.W.R. 329.

55. [1939] O.R. 517, affd. [1940] O.R. 140.

56. Actually the Supreme Court judgment in Lockhart came down five weeks before that of Howson J. in W.W. Sales but presumably was unavailable to him. 
Supreme Court in Lockhart after argument but before judgment in W. W. Sales in the Supreme Court.".7

An insurance case which arose out of a fire and another which arose from an explosion can conveniently be described here. In early 1932, a week before the Corona Hotel fire, a break in the service pipe on the premises of Empire Marble and Tile Co. resulted in an explosion and fire. That company brought an action in negligence against Northwestern Utilities. Ewing J. found that the defendant had negligently installed the service pipe so that it cracked, and gave judgment for the plaintiff. The trial took place in June 1933, some nine months before Steer joined the Milner firm. Milner and Martland had appeared for Northwestern at the trial and with them was S.C.S. Kerr, who represented Northwestern's insurer.

After the judgment the insurer denied liability and Kerr consulted Steer. When the latter joined the Milner firm, Kerr had no objection to his acting for Northwestern in its action on the policy, so Steer did appear. The case came to trial before Ewing J.. The defendant argued that Northwestern's liability to Empire Marble \& Tile was outside the coverage of the policy because the break in the service pipe occurred on private property, and the pipe was not part of Northwestern's "plant" which was all the policy covered. The trial judge held that Northwestern's liability in the original action was covered by the policy; and that even if it were not, the insurer by participating in the defence of the original action was precluded from denying liability, at least without having reserved its right so to do.

On the defendant's appeal the court did not call on Northwestern's counsel, Steer and Martland. Three of the judges held that the defendant's participation in the defence of the original action, especially in connection with negotiations for settlement, worked an estoppel. A fourth held the policy covered the loss while the fifth did not concur in the dismissal.

On further appeal, a unanimous Supreme Court held that Northwestern's liability in the original action was within the policy. The Court did not express a definite opinion on estoppel but suggested that inasmuch as the policy gave to the insurer a contractual right to co-operate in the defence, the exercise of that right could hardly give rise to an estoppel..$^{58}$

The second insurance case was Abasand v. Boiler Inspection and Insurance $C_{0 .}{ }^{59} \mathrm{~A}$ basand was a pioneer in efforts to mine the oil sands, extract the oil and refine it. It had a plant, small by present standards, near Fort McMurray. Its insurance policy gave Abasand compensation of $\$ 1000$ a day for each day of prevention of business as a result of a boiler explosion. The terms of the policy were rather complicated and created great uncertainty as to liability in the event which occurred.

On 21 November 1941 most of the plant was burned down. Abasand claimed $\$ 1000$ a day for the maximum period of 100 days while the insurer

57. Sub nom C.P.R. v. Lockhart [1942] A.C. 591 affg. [1941] S.C.R. 278.

58. [1935] S.C.R.291 affg. [1934] 3 W.W.R. 507 and 638 (App. Div.); compare Home Insurance Co. v. Lindal [1934] S.C.R. 33, where the Court found no estoppel when the insured had been driving while intoxicated.

59. [1945] 3 W.W.R. 49, affd. [1947] 1 W.W.R. 61, revd. [1948] S.C.R. 315 but restored [1949]2 W.W.R. 1068 (P.C.). 
denied liability. A basand sued. At trial Steer and Martland appeared for the plaintiff while L.H. Fenerty, and his son, R.L. Fenerty, both of Calgary were for the defendant. The plaintiff showed through expert evidence that there had been an explosion in the boiler. It damaged the boiler and produced a tongue of flame which lit a wooden beam nearby. The disastrous fire ensued.

One clause in the policy said that the compensation of $\$ 1000$ a day was payable for prevention of business when "caused solely" by an explosion. Another excluded liability for prevention of business resulting from fire outside the boiler following an explosion. The defendant relied heavily on these provisions. Their interpretation and application to the facts produced a remarkable division of opinion as the case went through the courts.

Mr. Justice Shepherd found for the plaintiff. The defendant's appeal was dismissed in a 3-2 judgment. Its further appeal to the Supreme Court was successful in another 3-2 decision. Space does not permit an analysis of the judgments on each side. They are all persuasive, both on causation and interpretation of the policy. Steer's persistence led Abasand to apply to the Privy Council for leave to appeal which was granted. With Steer on the appeal was Frank Gahan who had been on the opposite side in Northwestern Utilities. For the respondent was R.L. Fenerty who had been with his father in the courts below. The appeal was allowed.

\section{CONTRACTING OUT OF THE BENEFIT OF A STATUTE}

When a statute restricts the rights of $A$ as against $B$ or when it confers rights on $B$ as against $A$, may $B$ make an agreement with $A$ whereby $B$ contracts out of the benefit of the statute? If the statute specifically prohibits contracting out, that is the end of the matter, e.g., Pension Acts and Workmen's Compensation Acts. Many statutes contain no such specific prohibition - e.g., statutes restricting the rights of creditors as against debtors (of which there are a number in Alberta) and statutes conferring benefits such as the Intestate Succession Act and the Family Relief Act. The rule is this: $\mathrm{B}$ may contract out where the statute is merely for his benefit, but where the statute is in the public interest then B may not do so and thus notwithstanding his purported contracting out, may still invoke the statute.$^{60}$ One might add that A cannot enforce a remedy pursuant to B's purported contracting out when the Court lacks jurisdiction to grant that particular remedy. Steer had four cases on these problems. In the first three he contended B could validly contract out and in the fourth that he could not.

In the first two cases, in 1938, the facts were essentially the same. In a separation agreement the wife for consideration purported to give up her rights under the Intestate Succession Act and the Widows' Relief Act (forerunner of the Family Relief Act). In one case Steer argued for enforcement of the agreement and in the other Martland so argued. Howson J. gave judgment in both cases on the same day, holding that the wife could not contract out of either statute. Steer appealed one of the cases. The Appellate Division held that a wife could contract out of the Intestate Succession Act but not out of the Widows' Relief Act. Since the wife in that .case was claiming only under the latter Act, the appeal was dis-

60. See Laskin, "The Protection of Interests by Statute: The Problem of 'Contracting Out' " (1938) 16 Can. Bar Rev. 669. 
missed. ${ }^{61}$ The Testator's Family Relief Act which replaced the Widows' Relief in $1947^{62}$ has a somewhat different basis. Under the first Act the wife could apply if she received under the will less than she would have on an intestacy. Under the Family Relief Act she can apply if she did not receive adequate provision under the will. Our courts have held that the agreement cannot oust the jurisdiction of the court under the Family Relief Act, though of course the agreement can be considered in deciding the amount of the award under the Act. ${ }^{.33}$

Steer's third contracting out case, Mutual Life Assce. Co. v. Marks and Levitt ${ }^{64}$ arose just after the first two. The plaintiff had a first mortgage against Levitt's farm. Being badly in arrears, Levitt signed a memorandum consenting to foreclosure and waiving any rights under the Debt Adjustment Act. That Act, in language similar to that of the Statute of Frauds, and the Limitations Act, said "no action ... shall be taken, made or continued" without a permit from the Debt Adjustment Board. The plaintiff took the usual foreclosure action and obtained the order nisi for foreclosure. Marks was a second mortgagee. He applied to have the order nisi set aside. Ives J. refused the application and granted an order for foreclosure on 3 November, 1938.

Nineteen days later the Legislature amended the Act to provide that any agreement whenever made purporting to deprive any person of the benefit of the Act should be of no effect unless approved by the Debt Adjustment Board. The amendment was in effect when Marks' appeal came on. At first blush, it seemed to apply to the very situation before the court. However the court doubted that the document Levitt signed was an agreement under the section. In any case, the amendment did not make an agreement void. The court below had jurisdiction to make the order nisi. As to the validity of the foreclosure order, the court considered whether the Act was one passed for the public benefit. The court held it was not passed for the benefit of the public and certainly not of second mortgagees. The Act did not remove the court's jurisdiction to order foreclosure. It could be waived like the Statute of Frauds and the Limitations Act.

The fourth case is Crédit Foncier v. Edmonton Airport Co. and Superstein ${ }^{65}$ Superstein was the main shareholder in the defendant company which was formed to operate a hotel near Edmonton's International Airport. In February, 1961 the company borrowed $\$ 300,000$ from the plaintiff to build the hotel on the security of a mortgage on the property. Superstein executed a personal guarantee of the mortgage debt and waived any rights under the Judicature Act. That Act, in a carryover from the depression, forbade a money judgment on a mortgagor's covenant to pay, leaving the mortgagee to his remedies of sale and foreclosure.

The company soon defaulted. The plaintiff brought the usual foreclosure action and also sued Superstein on his guarantee. Steer acted for the defendants at the trial. The McCuaig firm for the plaintiff retained

61. Jones v. Kline [1938] 3 W.W.R. 65; Re Rist [1938]3 W.W.R. 101, affd. [1939] 1 W.W.R. 518 (App. Div.).

62. Testator's Family Relief Act, S.A. 1947 c. 12; now the Family Relief Act R.S.A. 1980 c. F-2.

63. See e.g., Re Berube [1973] 3 W.W.R. 180 (App. Div.).

64. [1939] 1 W.W.R. 530 (App. Div.).

65. (1964) 46 W.W.R. 221, affd. (1964) 48 W.W.R. 641, affd. [1965] S.C.R. 441. 
W.G. Morrow who was by this time a leader at the bar and was soon to begin a distinguished career as a judge. The trial was the first round of a long and at times acrimonious battle.

The issue of concern here had to do with the guarantee. Steer argued that Superstein's agreement to waive the Judicature Act meant that the mortgagee could obtain a money judgment against him and in so doing collect on the covenant - something the Judicature Act forbade. Thus a main issue in the case was whether a guarantor was within the protection of the Act and if so whether he could waive it. The other main issues - the validity of Superstein's acknowledgement of the waiver and the validity of the chattel mortgage to secure the mortgage debt - will not be considered here. The courts throughout found for the plaintiff on these issues.

The trial judge, Kirby J., assumed (just as the guarantee itself had assumed) that Superstein, the guarantor, was within the protection of the Judicature Act. He went on to consider the validity of the waiver. Steer argued that the Judicature Act provisions were passed as a matter of public policy and therefore could not be waived. Kirby J. however considered himself bound by an Appellate Division judgment ${ }^{66}$ on similar earlier provisions and held the waiver valid. That judgment had cited Mutual Life v. Levitt as authority for the same proposition. Hence Kirby J. granted the usual order nisi/order for sale.

The defendants appealed and replaced Steer by D.P. McLaws of Calgary. The majority upheld the judgment below, one judge on the same ground and two on a different ground, namely that a guarantor is not within the protection of the Judicature Act.

Mr. Justice Johnson, with whom Porter J.A. agreed, wrote a strong dissent. After a careful review of the cases he concluded that if one party could exact a waiver as a condition of some advantage to the other party, the effect of the statute would be nullified. To prevent this, the waiver should be held to be against public policy.

On the defendants' appeal to the Supreme Court, Steer was back as counsel and with him was the Honourable C.H. Locke of Vancouver who had retired from the Supreme Court in 1962. In a short unanimous judgment the court held the guarantee valid because the guarantor was not protected by the Judicature Act. It protected only the mortgagor. The court left open the question whether a mortgagor could waive the benefits of the Act. In the meantime the legislature enacted that waiver of the benefits was to be against public policy and void. ${ }^{67}$

In subsequent proceedings which were protracted and contentious, Steer continued to act. The plaintiff "bought in" at the sale for $\$ 275,000$, which was the value of the property, and there was a deficiency judgment against Superstein for some $\$ 200,0000^{88}$ The law reports do not show whether he ever paid it. The writer understands that some kind of a settlement was effected.

66. Re Seizures Act [1943] 2 W.W.R. 133.

67. S.A. 1964 c. 40 s. 3, now Law of Property Act, R.S.A. 1980 c. L-8 s. $41(5)$.

68. (1966) 55 W.W.R. 734 affd. (1966) 56 W.W.R. 623 (A pp. Div.). Steer argued without success (a) that the valuation was too low and (b) that the moneys spent by the receiver to keep the hotel in business were improper disbursements. 


\section{AGREEMENT NOT TO COMPETE AND CONSPIRACY IN RESTRAINT OF TRADE}

Covenants by a vendor and by an employee not to compete are commonplace; and so are actions in which the covenantor tries to escape from his covenant. It is trite to say that the covenant will be set aside if it is unreasonable as between the parties or contrary to the public interest: ${ }^{69}$ and it is now settled that the burden on the covenantee in attempting to enforce the covenant is heavier on an employer than it is on a purchaser.

In Garbutt Business College v. Henderson ${ }^{70}$ Henderson had been on the plaintiff's staff since 1917. In 1928 the parties signed a contract making him principal of the college. Henderson covenanted that for five years after expiration of the contract he would not be engaged in a business college in Calgary. He left the plaintiff's employment on May 31,1938 and the next day opened his own college, which he incorporated. He attracted students and Garbutt's enrolment fell.

Garbutt sued for an injunction and damages. Mr. Justice Howson granted the injunction and awarded damages. When the defendant appealed, his solicitor retained Steer as counsel. The Appellate Division dismissed the appeal. This was the first Alberta case thoroughly to canvass the principles. The judgments of Harvey C.J. and Ford J.A. remain of importance. The Chief Justice was clear and emphatic. He thought little of a person who breaks his contract. He recognized, however, that a covenant in restraint of trade is valid only if reasonable. Sometimes the covenant is too wide. This is often fatal to the whole covenant, whether the "overbreadth" has to do with time, place or scope. In this case, Henderson had covenanted among other things not to "be concerned in or interested financially or otherwise in a business college". The Chief Justice thought that this part of the covenant went too far, but that it was severable from the rest of the covenant not to compete. Subject to this, he upheld the injunction and the award of damages. There was a question as to whether Henderson's company should be liable for damages. The Chief Justice said it should because it committed the tort of interference with contractual relations. In his judgments over a forty-five year period, the Chief Justice rarely paid a compliment to counsel. Here he said: ${ }^{71}$

I would like to add a word of commendation and thanks to the counsel engaged for the very great assistance rendered the court in their careful analysis of the difficult questions of law involved in their written and oral arguments.

Ford J.A. referred to the "excellent argument of counsel" on the question: what is the covenantee entitled to protect himself against? His answer was - divulging of trade secrets and confidential information and enticing away of customers. The plaintiff came within this test. Ford J.A. thought that Henderson was more like a partner than an employee so that his covenant should be scrutinized with less stringency. Henderson launched an appeal to the Supreme Court but did not proceed.

Steer's other two cases under the heading "restraint of trade" were, respectively, a civil action for conspiracy and criminal proceedings on charges of unduly restricting competition.

69. Where the covenant is reasonable as between the parties, it is rarely held to be against the public interest; see, however, Baker v. Lintott (1981) 25 A.R. 513 (Alta. Q.B.).

70. [1939] 2 W.W.R. 276, affd. [1939] 3 W.W.R. 259 (App. Div.).

71. [1939] 3 W.W.R. 259 at 268. 
In the year 1933 a doughty English woman, Mrs. Floyd, had a confectionery shop on Jasper A venue. Ice-cream cones sold for five cents. Mrs. Floyd sold "double headers", to the irritation of other confectioners, notably one Lucas and one Strong, who were also on Jasper Avenue though much further west. Mrs. Floyd alleged that these men together with the Edmonton City Dairy and the Northern Alberta Dairy Pool conspired to injure her trade by refusing to sell ice cream to her over a period of four weeks. She consulted Steer shortly before he joined the Milner firm. He advised her that although the alleged facts, if proved, would establish a conspiracy, the damages were minimal and he advised against action. Mrs. Floyd then consulted the Milner firm, which brought action. Before it came on for trial Steer had joined that firm. He and Martland appeared for the plaintiff. H.H. Parlee and S. Bruce Smith (Parlee's junior partner who by this time was well-established as an eminent counsel) were for the Dairy while C. Becker and H.A. Dyde represented the Pool.

During argument there was a detailed presentation by each side of the leading civil cases on conspiracy, which at the time ended with Sorrell v. Smith. ${ }^{72}$ Mr. Justice Frank Ford found that there was no agreement between the two dairies. Each merely yielded for a few days to pressure from the retailers. He added by way of dictum that had the plaintiff proved a violation of the anti-combine provisions in the Criminal Code, and damage resulting therefrom, she would have succeeded in her civil action. This is of course a point on which there has been a difference of opinion.

This account does not do justice to the animated and at times humorous proceedings. The writer recalls Parlee, in the utmost good spirit, crossquestioning Mrs. Floyd closely on the size of the portions which she and her husband scooped out of the ice-cream can. ${ }^{73}$

The so-called "Tobacco case", involving charges of conspiracy in restraint of trade, came five years after the Floyd case and lasted for years. The writer's memory is that proceedings began when a man with a small grocery business in Edmonton complained that his supply of tobacco was cut off after he sold a pack of cigarettes for less than the going price. In any case, the Imperial Tobacco Company, W.C. Macdonald Ltd., various other manufacturers and a number of jobbers, over thirty in all, were charged on 27 February 1939 under section 498 of the Criminal Code with conspiracy to injure persons engaged in the manufacture, distribution and sale of tobacco. The preliminary hearing took several weeks and all the accused were remanded for trial. In Alberta a charge replaces the indictment by a grand jury, and the accused were accordingly charged after the preliminary.

The Crown retained A.L. "Art" Smith, who had been on the Corona Hotel case. He acted with H.J. Wilson. Wilson had wide experience in criminal and constitutional cases in his many years as a Crown solicitor and later as Deputy Attorney General. For Imperial Tobacco the leading counsel was L.A. Forsyth of the Montreal firm, Brown, Montgomery and McMichael (now Ogilvy, Renault). With him was C. Sinclair of Imperial Tobacco in Montreal. Steer acted for Macdonald. When the accused applied on November 18 to quash the charges Steer did not appear because

72. [1925] A.C. 700.

73. Floyd v. E.C.D. [1934] 3 W.W.R. 326. 
his client did not join in the motion. It would be tedious to recite the grounds of the application. Ewing J. rejected them all. ${ }^{74}$ However, he reserved a case for the Appellate Division although he doubted his right so to do. The Appellate Division held the trial judge had no authority to reserve a case until after trial and that there was no right of appeal from the refusal to quash. This judgment illustrates Chief Justice Harvey's vast knowledge of criminal procedure. ${ }^{75}$

The accused then applied for an order for particulars. On January 16, 1940, this application was heard by A.A. McGillivray J.A., who was most experienced in criminal matters. Steer joined in this application on behalf of Macdonald. The demand for particulars occupies five pages in the Western Weekly Reports. McGillivray J.A. directed the Crown to provide particulars of the conspiracy charged in each count. ${ }^{76}$

The trial began at the beginning of May before Mr. Justice McGillivray and a jury of six. The law reports do not record the trial. The writer's memory is that the trial judge made a ruling that a huge number of documents seized from various defendants were inadmissible, and that the Crown decided it would be most difficult to prove the offences without those documents. In any case the Attorney General filed a stay of proceedings on May 10.

On November 19, the Crown laid charges under the Combines Investigation Act. They alleged the same conspiracy as that outlined in the original charge. The accused applied to quash the indictment and Shepherd J. denied the application. Then the accused made a demand for particulars which the Crown delivered on January 29,1941. The accused then applied to Shepherd J. for further and better particulars. He held the particulars already delivered to be adequate. ${ }^{7 ?}$

Throughout the proceedings Macdonald had disassociated itself from Imperial. On this second charge Macdonald decided not to be represented at all. Imperial thereupon engaged Steer to represent them, along with Messrs. Forsyth and Sinclair. J.C. McRuer of Toronto, who was then an eminent Crown counsel and later had a distinguished career as a judge, appeared with H.J. Wilson for the Crown.

The day after the new charges were laid, namely on November 20,1940, a Justice of Peace issued a search warrant authorizing the seizure of documents in the office of Imperial Tobacco Sales Co. in Calgary. Counsel for Imperial applied to Ives J. to quash the warrant. He refused and Imperial appealed. The Appellate Division quashed the warrant on the ground that the information and belief of the informant was based on information from the agent of the Attorney General. ${ }^{78}$

The search warrant was quashed on March 31, 1941. Shortly afterwards the case went to trial before Shepherd J. and a jury. At the end of a trial lasting 55 days the accused were convicted and fined. Macdonald Tobacco was the only one of the accused not to appeal. The argument of the appeal took fifteen days. Among a number of grounds, the appellants

74. [1939] 3 W.W.R. 394.

75. [1939] 3 W.W.R. 577.

76. (No. 2) [1940] 1 W.W.R. 124.

77. (No. 3) [1941] 1 W.W.R. 393.

78. [1941] 1 W.W.R. 401. 
relied on section 28 of the Combines Investigation Act. It said no person should be charged under that Act at the same time as he was charged on the same facts under section 498 of the Code. The court held that the charge under section 498 , though stayed, remained in existence. Thus section 28 came into play and the conviction could not stand. ${ }^{79}$

Mr. Justice Clarke had died before delivery of judgment. The other four members of the court were unanimous. The Crown applied to stay the entry of judgment and for reargument. Section 32 of the Judicature Act said that when a judge had died the remaining judges might give judgment if unanimous or if the judgment of the dead judge could not affect the result. The Crown argued that Clarke J. might have dissented on a point of law and so have given the Crown a right of appeal to the Supreme Court of Canada, and that section 32 could not validly apply to criminal cases. Chief Justice Harvey reviewed the history of majority judgments. He seemed almost indignant at the suggestion that section 32 did not apply to criminal cases, and he rejected it.

The Crown then in May, 1942, applied to Hudson J. of the Supreme Court for leave to appeal. The application was refused. So ended this lengthy and hard-fought contest. ${ }^{.1}$

\section{CONSTITUTIONAL CASES: ALBERTA'S DEBT LEGISLATION}

This part will include a description of some cases in which Steer did not take part. This is necessary to a coherent account. ${ }^{82}$

In Alberta, legislation to relieve debtors preceded the depression. In World War I the Volunteer and Reservists Relief Act, later called the Soldiers Relief Act, provided for the staying of actions for debt and for enforcement of mortgages until two years after the end of the war, or discharge. ${ }^{83}$ Then in 1922, just after the United Farmers of Alberta came to power, the Drought Area Relief Act, as its preamble stated, was designed to enable farmers in the drought area in Southeastern Alberta to maintain themselves until the 1923 harvest, and to protect them against "a multiplicity of actions". ${ }^{84}$

In 1923 this Act was succeeded by the first Debt Adjustment Act. ${ }^{85}$ Part I provided for a director whose task was to try to bring about the amicable settlement of farmers' debts. Part II dealt with farmers in the drought area. On the filing of a certificate in court that a farmer was entitled to the benefits of Part II, no action for foreclosure or seizure of property could be brought against him without leave of a judge.

In 1931, early in the depression, a new Act extended to the whole province the provision for filing a certificate in court. ${ }^{86}$ The next year the Act was made applicable to merchants. ${ }^{87}$ Then, as the depression deepened,

79. R. v. Imperial Tobacco Co. (No. 4) [1942] 1 W.W.R. 363.

80. R. v. Imperial Tobacco Co. (No. 5) [1942] 1 W.W.R. 625.

81. A.G. v. Imperial Tobacco Co. [1942] 3 D.L.R. 33 (S.C.C.).

82. On the constitutional issues considered in this and the next part see Mallory, Social Credit and the Federal Power in Canada (reprinted 1976).

83. S.A. 1916 c. 6, as am S.A. 1918 c. 25.

84. S.A. 1922 c. 43.

85. S.A. 1923 c. 43.

86. S.A. 1931 c. 57.

87. S.A. 1932 c. 18. 
the legislature took more drastic action. On 6 March, 1933, it amended the 1931 Act to forbid actions for debt against farmers and against resident homeowners in relation to their homes, without a permit from the director. This prohibition applied only to debts which arose before July 1, $1932 .{ }^{88}$ The amendment was a stop-gap. A month later the legislature passed a new Act which embodied the amendment and established a Debt Adjustment Board. ${ }^{89}$

Steer began to look into the question of constitutional validity almost as soon as the 1933 Act was passed. This was his first venture into constitutional law. He was convinced the Act was ultra vires and on more than one occasion hoped to test it, and its successor Acts of $1936^{90}$ and of $1937 .^{91}$

Social Credit replaced the U.F.A. as the party in power in 1935. This was the beginning of William Aberhart's stormy eight year tenure as premier. The legislation passed at the first 1936 session has no relevance to the present account. However, the second session saw a Reduction and Settlement of Debts Act. It said that for "old debts" (those arising before July 1,1932 ), the creditor could recover only the balance as of that date, reduced by subsequent payments of principal and interest, with no interest to be payable, and the balance to be paid over ten years. For new debts the creditor could collect only 5 per cent simple interest, less all sums paid. ${ }^{92}$

In a matter of months Ewing J. heard argument in six cases, consolidated for trial. The plaintiffs, who were all creditors, challenged the Act. Counsel were George B. O'Connor, R.D. Tighe, S.W. Field and G.H. Steer all of Edmonton and William McLaws and H.G. Nolan of Calgary. William S. Gray and James Frawley appeared for the Crown. All eight were King's Counsel. A principal attack on the Act was that it was legislation in relation to interest, and of course that subject belongs to Parliament under the B.N.A. Act. The government argued that the scope of the term "interest" was narrow - that it covered only usury legislation, and not legislation dealing with contractual interest generally. Ewing J. accepted the plaintiff's argument. On the Crown's appeal, the main arguments for the respondents were made by S.B. Woods and Steer. Chief Justice Harvey upheld the ruling of Ewing J., and went farther. He held that the Act gave the Lieutenant Governor the function of initiating legislation; that one section was an improper delegation to the Lieutenant Governor of the power to legislate; that the Act conflicted with the Bills of Exchange Act, the Bankruptcy Act and the Farmers' Creditors Arrangement Act; and that in the case of mortgages payable outside Alberta the legislation was bad as relating to civil rights outside the province..$^{93}$

Shortly after this decision, in the fall of 1937, a curious episode occurred. The Lieutenant Governor in Council made three Orders in Council amending the Rules of Court. They were never Gazetted. They forbade a Clerk of the Court from issuing a statement of claim which challenged

88. S.A. 1933 c. 11.

89. S.A. 1933 c. 13.

90. S.A. 1936 (2nd sess.) c. 5.

91. S.A. 1937 c. 9.

92. S.A. 1936 (2nd sess.) c. 2.

93. Credit Foncier v. Ross [1937]2 W.W.R.353 (App. Div.) affg. sub nom Royal Trust v.A.G. [1937] 1 W.W.R. 376. 
the validity of provincial legislation without the permission of the Lieutenant Governor in Council. Steer immediately drew a statement of claim in a routine foreclosure action, and included a prayer for a declaration that the Debt Adjustment Act was invalid. Expecting the Clerk of the Court at Edmonton, R.P. Wallace, to refuse pursuant to the Order in Council, he prepared the papers for an order of mandamus. However, the Clerk accepted the statement of claim because according to Rule 5 of the Rules of Court, the amending rule, unless it provided otherwise, was effective fifteen days after Gazetting. Thus the amendment was not in effect and the Clerk quite properly was prepared to accept the statement of claim.

On September 24 a new Order in Council, to the same effect as the amendments just described, repealed them and enacted similar provisions effective the next day, September 25 . Two days later, Steer issued a statement of claim in a foreclosure action, adding a prayer for a declaration of invalidity of the Debt Adjustment Act. Pursuant to the new amendments the Clerk declined to file it. Thereupon the plaintiff in the foreclosure action sued the Clerk of the Court for damages of $\$ 5000$ for refusing to issue the statement of claim. The case came on before Ives J. on October 20. In a thirteen-line oral judgment he found the new Rules to be in effect an amendment to the Judicature Act. "The executive arm of the government cannot do it, it requires the legislature to do it." The judgment was for one dollar damages "as asked for", together with a declaration that the Order in Council was invalid and of no effect. ${ }^{94}$

The summer and fall of 1937 produced other dramatic events. On August 17, 1937 the Governor General in Council disallowed three key statutes. ${ }^{95}$ Six weeks later the Lieutenant Governor reserved assent to three more bills. ${ }^{96}$ The Province challenged the validity of the powers of disallowance and reservation, but failed. ${ }^{97}$ Then, as to the three reserved bills, the Supreme Court held all invalid. On appeal, the Judicial Committee agreed that the Bank Taxation bill was invalid but did not pass on the other two because they depended on the Alberta Social Credit Act, ${ }^{98}$ which had been repealed just after the Supreme Court judgment. ${ }^{99}$ Steer was not among the battery of lawyers on this case.

Reference has been made to the Debt Adjustment Act. In 1941, in a case from Calgary, the Supreme Court held the Act inapplicable to an action on a promissory note. ${ }^{100}$ Steer was not on this case. It did not hold the Act to be invalid. However, its reasoning encouraged attack on the Act and indeed on other provincial legislation which allegedly conflicted with federal statutes.

94. Steen v. Wallace [1937] 3 W.W.R.654. It is clear from the judgment that Steer asked for only nominal damages.

95. The Credit of Alberta Regulaton Act, S.A. 1937 (2nd sess.) c. 1; The Bank Employees' Civil Rights Act, S.A. 1937 (2nd sess.) c. 2; An Amendment to the Judicature Act, S.A. 1937 (2nd sess.) c. 5.

96. The Bank Taxation Act, 1937 (3rd sess.) Bill 1; The Credit of Alberta Regulation Act, 1937 (3rd sess.) Bill 8; The Accurate News and Information Act 1937 (3rd sess.) Bill 9. These bills appear in S.A. 1937 (3rd sess.) pp. 31-39.

97. Re Dissallowance and Reservation [1938] S.C.R. 71.

98. S.A. 1937 c. 10.

99. Re Three Alberta Bills [1939] A.C. 117, affg. in part [1938] S.C.R. 100.

100. A.G. v. Atlas Lumber Co. [1941] S.C.R. 87, affg. A tlas Lumber Co. v. Winstanley [1940]1 W.W.R. 35. 
The Legislature in the spring of 1941 enacted a Debt Proceedings Suspension Act 1941, ${ }^{101}$ and an Orderly Payment of Land Debts Act ${ }^{102}$ They were disallowed, along with a Draconic amendment to the Limitations Act, ${ }^{103}$ on March 27, 1942. ${ }^{104}$ In the meantime, O'Connor J. had held the Orderly Payment of Land Debts Act to be invalid, but the Appellate Division said the problem was not before him. ${ }^{105}$

As to the Debt Adjustment Act itself, mortgage companies were not eager in the early years to attack its validity. The Debt Adjustment Board, in the writer's opinion, administered the Act in a responsible way. The director, W.N. Loree, was able and fair. However by 1940 the practice of the Board was to require the applicant for a permit to agree to a settlement on the lines of the Reduction and Settlement of Debts Act which, as described above, had been held invalid. The writer recalls four cases in October 1940. Each involved a mortgage held by a client of Steer's on an Edmonton home. The mortgagor's taxes were in arrears and the City was in position to take title. On application to the Board for a permit, in each case the Board insisted on an offer of settlement. Thereupon Steer on his client's instructions issued a statement of claim in each case. He was prepared to meet a defence based on the absence of a permit by an allegation that the Act was invalid. However these cases did not test the Act. As best the writer can recall, the debtors began to make payments.

Around the same time a mortgagee represented by the Newell Emery firm brought an action without a permit. ${ }^{106}$ The sole defence was absence of a permit. The plaintiff argued invalidity of the Act on six grounds. O'Connor J. rejected five of the grounds but accepted the sixth - the Act was insolvency legislation. His judgment was handed down on March 14, 1941. On that same day the legislature enacted the Legal Proceedings Suspension Act, $1941 .^{107}$ It provided for a sixty-day stay of actions challenging the Debt Adjustment Act. In the action just described, O'Connor J. held the legislature could not prohibit or delay proceedings to challenge the validity of its legislation. ${ }^{108}$

One might wonder why this case did not proceed further. The reason is that the Governor General referred to the Supreme Court of Canada five questions respecting the validity of the Debt Adjustment Act. ${ }^{109}$ On the argument in June, 1941, Steer was not among the twelve lawyers who took part in the argument on one side or the other. Alberta lawyers were Messrs. Tighe, McLaws, Gray and Frawley. Eastern counsel included Messrs. Geoffrion, Varcoe, Tilley, Leonard, McMichael, and Louis St. Laurent. These men need no identification; nor does J.W. De B. Farris of Vancouver who also appeared.

Chief Justice Duff speaking for six of the seven judges (Crocket J. dissenting) found that the Act struck at the substance of creditors' rights,

101. S.A. 1941 c. 41.

102. S.A. 1941 c. 47.

103. S.A. 1941 c. 62.

104. S.A. 1942 p. 337 lists the disallowances.

105. Plourde v. Roy [1942] 1 W.W.R. 193 and 696 (App. Div.).

106. North American Life Assce. Co. v. McLean [1941] 1 W.W.R. 430.

107. S.A. 1941 c. 3 (not to be confused with The Debt Proceedings Suspension Act, S.A. 1941 c. 41).

108. North American Life Assce. Co. v. McLean (No. 2) [1941] 1 W.W.R. 588.

109. Re Debt Adjustment Ach, 1987, [1942] S.C.R. 31. 
some of which were conferred by federal legislation - the Bills of Exchange Act, the Bank Act and the Companies Act. Moreover, it attempted to establish authority over banks and federal undertakings and companies incorporated under the Dominion Companies Act. Finally, it brought compulsion on creditors of an insolvent debtor and so was legislation in relation to bankruptcy. The judgment came down on December 2 , 1941. On March 19, 1942 the Alberta legislature passed the Legal Proceedings Suspension Act, $1942 .{ }^{110}$ It recited the pending appeal to the Privy Council on the Debt Adjustment Act, and it postponed until after the decision actions to which that Act applied. The Lieutenant Governor referred to the Appellate Division the question of its validity. McCuaig appeared for the Alberta Mortgage Loans Association, and Steer for the Canadian Bankers Association, while W.S. Gray and Wilson defended the Act. In a 3-2 decision the majority held the Act to be an indirect method of keeping in effect an Act which the Supreme Court had held invalid. ${ }^{111}$

As to the Debt Adjustment Act itself, the Province's appeal to the Judicial Committee was argued for eight days near the end of 1942. On February 1,1943 the appeal was dismissed on the ground that the Act invaded Parliament's power in relation to bankruptcy and insolvency and interfered with Parliament's legislation on those matters. ${ }^{112}$

When the legislature passed the Legal Proceedings Suspension Act, 1942 , discussed above, it also amended the Judicature Act ${ }^{113}$ to provide for a one-year period of redemption in actions on a mortgage or agreement for sale with power in the court to increase or decrease the period. Steer was not on the case which attacked the amendment. In a 3-2 judgment the Appellate Division held it invalid as another attempt to keep the Debt Adjustment Act alive pending the Privy Council decision. The Supreme Court upheld the amendment in a short judgment. ${ }^{114}$

In 1946 the Alberta legislature made a final effort to control banks in the province. It enacted the Alberta Bill of Rights Act. ${ }^{115}$ Part I was innocuous but Part II asserted control over banks in connection with the issuing of credit. The Act itself provided for a reference to the Appellate Division as to its validity. Steer and Alexander Smith ${ }^{116}$ appeared for the Attorney General of Canada while E.J. Chambers and Stanley Edwards of Calgary represented the Canadian Bankers Association. The Appellate Division upheld Part I but held Part II invalid as legislation in relation to banking. The Province appealed to the Privy Council and the Attorney General of Canada cross-appealed. On that hearing, Steer had with him David Mundell, an able young lawyer who had been counsel to the Royal Commission on Espionage. The Judicial Committee held the two

110. S.A. 1942 c. 5.

111. Re Legal Proceedings Suspension Act, 1942, [1942] 2 W.W.R. 536 (App. Div.).

112. Sub nom A.G. for Alberta v. A.G. for Canada [1943] A.C. 356.

113. S.A. 1942 c. 37.

114. Roy v. Plourde [1943] S.C.R. 262, revg. Plourde v. Roy (No. 2) [1942] 2 W.W.R. 607.

115. S.A. 1946 c. 11.

116. Smith had been articled to Steer in $1941-42$ and during the next five years worked closely with him on the constitutional cases. He taught Constitutional Law during this period. In 1947 he joined the Faculty of Law as Professor and so remained until retirement in 1973. His text, The Commerce Power in Canada and the United States (1963), is an acknowledged classic. 
parts of the Act to be so interwined that Part I was not severable and since Part II was invalid, Part I fell with it. ${ }^{117}$

\section{INTEREST ON PROVINCIAL AND PROVINCIALLY-GUARANTEED BONDS}

When Social Credit came to power in 1935, the new government found the treasury to be "empty", in the words of an Order in Council of May 30, 1936. That Order reduced the rate of interest on government bonds and on bonds guaranteed by the government. In general the amount of interest was halved. On 1 September, 1936 a Provincial Securities Interest Act validated the Orders in Council. ${ }^{118}$

A fraternal order named the Independent Order of Foresters (I.O.F.) held a substantial number of provincial bonds and also bonds of the Lethbridge Northern Irrigation District, guaranteed by the province. The I.O.F. presented to the Imperial Bank in Toronto the Lethbridge Northern coupons due on November 1, 1936. The Bank offered the reduced amount which the I.O.F. refused. The I.O.F. retained Steer, who brought action on January 5,1937 to recover the unpaid interest on the guaranteed bonds. In February, 1937 Ives J., in one of his typical laconic judgments, held the Act to be legislation in relation to interest and gave judgment for the arrears. ${ }^{119}$ An appeal by the Crown was abandoned when the legislature replaced the Act by three new ones. These were enacted on April 14,1937. The first Act (Chapter 11) barred actions on guaranteed bonds without consent of the Lieutenant Governor in Council. The second (Chapter 12) reduced the interest on guaranteed bonds and the third (Chapter 13) reduced the interest on government bonds. The reduction was the same as it had been in the previous Act held invalid by Ives J..

When the I.O.F. went to tax its costs and to issue execution on $\mathrm{Mr}$. Justice Ives's judgment, the government invoked Chapter 11 and the Clerk felt bound to refuse to tax the costs or to issue execution. Then when the next coupons fell due on May 1,1937, the bank again refused to pay them in full. Thereupon Steer on behalf of the I.O.F. brought another action claiming payment of the judgment and of the amount of the coupons for May 1, and for a declaration that the two Acts relating to guaranteed securities were ultra vires.

Mr. Justice Ewing held that an Act barring, or one like Chapter 11 requiring leave to bring, an action which challenged the validity of a provincial act would nullify the constitution and thus was unconstitutional. Then he went on to hold that Chapter 12 was in relation to interest and that it conflicted with the Interest Act which says that a lender may exact the interest agreed upon. The Appellate Division upheld this judgment. ${ }^{120}$

Thus far the actions were confined to the Lethbridge Northern bonds. Alberta had no Crown Proceedings Act at the time, and proceedings against the Crown were by petition of right. The I.O.F. presented a petition for a declaration that Chapter 13 was invalid. Mr. A berhart, who was Attorney General as well as Premier, signed the fiat "Let right be done."

117. A.G. of Alberta v. A.G. of Canada [1947]A.C. 503 revg. in part Re Alberta Bill of Rights Act [1946] 3 W.W.R. 772 (App. Div.).

118. S.A. 1936 (2nd sess.) c. 1.

119. I.O.F. v. Leth. Nor. Irrig. Dist. [1937] 1 W.W.R. 414.

120. I.O.F. v. Leth. Nor. Irrig. Dist. (No. 2) [1938] 2 W.W.R. 194 (App. Div.), affg. [1937] 3 W.W.R. 424. 
The case came before Shepherd J. on February 11, 1939. He held Chapter 13 to be invalid as interest legislation and also on the ground that it interfered with the right to collect interest outside the province. The appeal was heard in Calgary and dismissed in a short judgment. ${ }^{121}$

At this point the Province, which of course had the carriage of both proceedings, appealed to the Privy Council. The appeals were heard over four days in December, 1939, just after war had broken out. Gray for the Crown had with him D.N. Pritt, K.C., a prominent English barrister, while with Steer was Frank Gahan, who has been mentioned earlier. Both appeals were dismissed. ${ }^{122}$

There was no way to enforce payment of the arrears on the provincial bonds. Over five years later, in July 1945 after "protracted discussions and negotiations" with bondholders' committees, the Government made an offer to bondholders pursuant to an elaborate Debt Reorganization Programme. It covered guaranteed bonds as well as government bonds. ${ }^{123}$

In the meantime, Steer persisted in his efforts to collect the judgments against Lethbridge Northern. The I.O.F. issued execution and garnisheed moneys owing to the judgment debtor. The province also was execution creditor of Lethbridge Northern in a huge sum - over three and a half million dollars. The province claimed its share of the monies garnisheed and of the property seized under the writ of execution. Mr. Justice Hugh John Macdonald directed an issue, and after the pleadings were closed the parties agreed to state a special case respecting the right of the Crown to share. This issue came on before $\mathrm{Mr}$. Justice $\mathrm{O}^{\prime} \mathrm{Connor}$ in July, 1943. He held that the Crown as guarantor could not compete with the I.O.F., but added a "rider" that the I.O.F. would have to share with other debenture holders. ${ }^{124}$ Steer appealed the "rider" and the Crown cross-appealed. Frank Ford J.A. for the Appellate Division dismissed the cross-appeal and allowed the appeal on the ground that the rider was outside the terms of the special case. ${ }^{125}$

The last reported episode in this long story was an attack by the Provincial Treasurer and by Lethbridge Northern on the validity of the plaintiff's garnishee and seizure under the writ of execution. Their argument was that the money and property seized were held by Lethbridge Northern in trust for the provincial treasurer. By this time the I.O.F. had recovered a third judgment against Lethbridge Northern for some $\$ 61,500$. McLaurin J. held that there was no trust and moreover that there was no need for the I.O.F. to sue on behalf of all the bondholders; that the right of the sheriff to satisfy judgments by striking a rate was not the I.O.F.'s only remedy; and finally that nothing in public policy prevented execution against an undertaking like Lethbridge Northern. The defendants' appeal was dismissed. ${ }^{126}$

The constitutional cases on legislation to relieve debtors, to control banks, and to reduce interest on provincial bonds, covered more than a

121. I.O.F. v. The King [1939] 1 W.W.R. 700 (App. Div.), affg. [1939] 1 W.W.R. 275.

122. Leth. Nor. Irrig. Dist. v. I.O.F.; The King v. I.O.F. [1940] A.C. 513.

123. O.C. 1168-45, July 17, 1945; Alberta Gazette Vol. 41 p. 705; see Re Ramsey Trust Deeds [1946] 1 W.W.R. 510.

124. I.O.F. v: Leth. Nor. Irrig. Dist. [1943] 3 W.W.R. 297.

125. [1944] 1 W.W.R. 206.

126. I.O.F. v. Leth. Nor. Irrig. Dist. [1945] 1 W.W.R. 121 affg. [1944] 3 W.W.R. 49. 
decade. By the time the Privy Council decided the reference on the Bill of Rights Act in 1947, the depression was over, World War II was over and the Honourable Mr. Manning had been Premier for four years. The drastic legislation of the early Social Credit period was a thing of the past and so was the bitter litigation and the unusually large number of disallowances - ten of them between August 1937 and March 1942. ${ }^{127}$

There was, however, a mild revival of the old issues over debt legislation with the passage of the Orderly Payment of Debts Act, 1959. ${ }^{128}$ It allowed a debtor to apply to the Clerk of Court for an order consolidating his debts. On the making of the order a creditor with a claim of $\$ 1,000.00$ or less was bound by the scheme of the Act. The Lieutenant Governor in Council referred to the Appellate Division the question of its validity. ${ }^{129}$ The Court appointed Steer to represent creditors or others opposed to the Act. The Appellate Division held that the element of compulsion on creditors made the Act invalid as insolvency legislation. On the Crown's appeal to the Supreme Court of Canada, three sets of reasons reached the same conclusion as that of the Appellate Division. Subsequently, Parliament amended the Bankruptcy Act by adding Part X entitled Orderly Payment of Debts. ${ }^{130}$

\section{MISCELLANEOUS CONSTITUTIONAL CASES}

In 1950 Steer had a constitutional case that had no connection with Alberta. It arose out of Newfoundland's entry into Confederation on March 31, 1949. Between 1915 and 1949 twelve Newfoundland statutes granted to Bowater's Newfoundland Pulp and Paper Mills exemptions from certain taxes and customs duties. These exemptions extended to a date beyond 1949. On December 10,1949 Parliament amended the Income Tax Act to abolish all these exemptions. ${ }^{131}$ The Governor in Council promptly referred to the Supreme Court of Canada three questions which asked whether Bowater's was still entitled to (1) exemptions from duty or tax (2) exemptions from obligations imposed by Parliament respecting duty or tax and (3) exemptions from Acts of Canada requiring a license, permit or certificate for export or import of goods. ${ }^{132}$

The writer's understanding is that Bowater's had originally retained J.R. Cartwright of Toronto and that when he was appointed to the Supreme Court of Canada on 22 December, 1949, Bowater's retained Steer in his stead. In any case, he appeared on the reference and with him were Eastern counsel, C.F.H. Carson and C.G. Heward. The company argued that the content of "Bowater's law" was such that in part it fell under provincial jurisdiction and in part under federal, and that the two were so interwoven that legislation at both the federal and provincial level was necessary to remove the exemptions which Bowater's had enjoyed. Only Taschereau J. agreed with this argument. The majority upheld the federal power.

127. S.A. 1942 p. 337 lists them.

128. S.A. 1959 c. 61.

129. Re Orderly Payment of Debts Act. 1959, [1960] S.C.R. 571 affg. 29 W.W.R. 435 (App. Div.).

130. S.C. $1966-67$ c. 32 s. 22 , now R.S.C. 1970 c. B-3, Part X.

131. S.C. 1949 (2nd sess.) c. 24 s. 49.

132. Re Bowater's Nfld. Pulp \& Paper Mills Ltd. [1950] S.C.R. 608. 
The next two cases are included here rather than with the oil and gas cases because they are related to the transfer of natural resources from Canada to the prairie provinces in 1930 and so have a constitutional aspect. The first case is $A$.G. v. Whiteshore Salt Company, ${ }^{133}$ from Saskatchewan. Whiteshore held sixteen leases or licenses for the mining of alkali (sodium sulphate), and granted by the federal government before the transfer of natural resources to the Province. In 1931 the Province, at the Company's request, consolidated the leases into two leases. In 1937 they were renewed for 20 years. The legislature amended the Mineral Resources Act in 1947 to require lessees and licensees to pay such royalties as the Regulations might impose. An Order in Council of the same year increased Whiteshore's royalty. Whiteshore contended that the Province had no power to impose the increase. The trial judge agreed. The original leases had not been surrendered but rather had been renewed, and the agreement for the transfer of natural resources forbade an increase in royalties from subsisting leases. The Saskatchewan Court of Appeal affirmed. On the Province's appeal to the Supreme Court, Steer joined E.C. Leslie, the prominent Regina practitioner, as counsel for Whiteshore. They lost in a 3-2 decision. The majority held that the original leases from the federal Crown were surrendered when the consolidation took place in 1931. The new leases did not purport to be renewals. Thus the Province had power to increase the royalties.

Another case involving royalties is Huggard Assets v. A.G. of Alberta. ${ }^{134}$ In 1913 the Canadian government granted to Huggard's predecessor the oil and gas rights in 1320 acres near Fort McMurray. Huggard acquired title. The grant from the Crown had provided for payment of "such royalty upon the said petroleum and natural gas, if any, from time to time prescribed by regulations". The federal government had never imposed a royalty. The agreement to transfer natural resources in 1930 provided that royalties should go to the province. The province claimed the right to impose a royalty. Huggard then brought action for a declaration that the royalty was not exigible.

At the trial S.W. Field appeared for the company and H.J. Wilson for the Crown. Boyd McBride J. held that the royalty clause permitted only the collection of a royalty which had been imposed at the time of the grant. Therefore the company was free from any imposition by the province. In other words, the court found the words ambiguous and construed them against the grantor in whose favour royalties would be payable. The grantor was the Crown in right of Canada and the Province stood in its shoes.

On appeal, the Appellate Division sat with four members, probably because Chief Justice Harvey had just died. The Court was equally divided so the judgment stood. The Province appealed to the Supreme Court of Canada. At this point the federal Government retained Steer. He supported the provincial contention. During argument in May, 1950, the Court raised a new question - is the Statute of Tenures, $1660,{ }^{135}$ in force in Alberta? If so, does it prohibit the imposition of the royalty? A rehear-

133. A.G. v. Whiteshore Salt Co. [1955] S.C.R. 43 revg. [1952] 4 D.L.R. 51 (Sask. C.A.).

134. A.G. for Alberta v. Huggard Assets [1953] A.C. 420 revg. [1951]S.C.R. 427, affg. [1950] 1 W.W.R. 69 affg. [1949] 2 W.W.R. 370.

135. 12 Car. II c. 24. 
ing was ordered to deal with this question. ${ }^{136}$ Field, Wilson and Steer were all scholarly. The writer doubts, however, that they ever expected to have to debate the intricacies of mediaeval English law of real property in a case from Alberta in the twentieth century. These new questions sent them scurrying to examine Pollock and Maitland, Coke, Blackstone and Challis.

Just what was this Statute of Tenures (more accurately called the Statute to Abolish Military Tenures)? How could it have anything to do with the law of Alberta, which remained unexplored and indeed undiscovered for almost a century after 1660 ?

To answer the first question one must look to the land law of feudal England. The main "freehold tenures" were knight's tenure and common socage. The latter lacked the prestige of the former, but the services or payments due to the King (from whom all land was, and still is, held) had the virtue of being certain. Knight's tenure, though more honourable, carried with it burdens including the King's right of wardship and of various "aids" or levies. The amount of these exactions was uncertain. By the time of the English Civil War the feudal age was past, and knight's tenure an anachronism. Thus in the year of the restoration of Charles II, Parliament completed a move which had been started before the Civil War to abolish tenure by knight's service and the other military tenures. The Act recites that the consequences of knight's tenure "have been much more burthensome, grievous and prejudicial to the Kingdom than they have been beneficial to the King". Then the Act, which takes up fourteen pages in the Statutes at Large, abolished knight's tenure and converted estates in land so held into free and common socage. To compensate the King for the loss of revenues, he was empowered to impose various rates and duties.

Ten years later the King granted Rupert's Land to the Hudson's Bay Company "in free and common socage". In return, the company by way of "reddendum" had to make a yearly payment of "two Elcks and two black beavers when and so often as Wee our heirs and successors shall happen to enter" Rupert's Land. The "payment" was made in Winnipeg when George VI visited Canada in 1939. This was pure ceremony because the Company had surrendered Rupert's Land in $1869 .{ }^{137}$

Rupert's Land became part of Canada on July 15,1870. A portion of it became the Northwest Territories, and in 1905, part of the Territories became the Province of Alberta. The North-West Territories Act $1886^{138}$ provided in section 3 that the laws of England as of $15 \mathrm{July} 1870$ "shall be in force in the Territories, insofar as the same are applicable to the Territories."

After the rehearing before the Supreme Court in October, 1950, the Province's appeal was dismissed in a 4-3 judgment. The minority held that Huggard received a conditional fee and that the condition (payment of royalty) was clear. The royalty clause contemplated the possibility of an imposition of royalties at some time in the future. The majority did not

136. It is clear that the Supreme Court rejected the reasoning of Boyd McBride J. and held that the royalty clause did literally provide for future royalties. The main question in the rehearing was whether the reservation of royalties was "invalid on the ground of uncertainty or any other ground".

137. The writer's understanding is that delivery of the elk and beaver was made by Sir Ashley Cooper, Governor of the Company.

138. 49 Vict. c. 25 (Can.). 
disagree with this, but in upholding the judgment below did so on a completely different ground - namely that the amount of royalty was uncertain and therefore void. The Statute of Tenures was in force in Alberta and it required that any "service" (which includes a royalty) to the Crown must be certain. The policy of the Statute of Tenures was to put an end to the evil of allowing the Crown arbitrarily to determine the amount of services to be rendered or payments to be made by a grantee of land.

The province appealed to the Privy Council. Steer did not appear on that hearing. The federal Crown was represented by Frank Gahan who was by now a Queen's Counsel. The Saskatchewan government intervened to support the provincial position and was represented by M.C. Shumiatcher.

The Privy Council reversed the Supreme Court on these grounds. (1) The provision for royalties was probably not uncertain. The "reddendum" in the charter of the Hudson's Bay Company had itself been uncertain in a sense because it was payable only when the monarch came to Rupert's Land, and yet it clearly was valid. (2) The Statute of Tenures was probably not applicable to Rupert's Land. It would seem odd that an Act designed to put an end to the peculiarities of mediaeval land tenure in England was intended to apply to a new and remote colony. In any case, the grant to the Hudson's Bay Company was not in knight's tenure but in free and common socage.

The Privy Council said there were then two questions: (1) is the variable royalty inconsistent with free and common socage? (2) even if it is, has subsequent legislation validated the variable royalty? On the first question, the Judicial Committee held that the variable royalty is probably certain but "rather than plunge into the jungle of learned disagreement" 139 on this point, their Lordships assumed that the variable royalty is not certain. That required an answer to the second question, and the decision was that the Dominion Lands Acts of 1886 and 1908 show that Parliament intended to give power to deal with hard cases in a way that infringes "free and common socage". ${ }^{140}$ Thus the variable royalties were valid.

\section{TWO CRIMINAL LIBEL CASES: "BANKERS" TOADIES" AND "BABIES FOR EXPORT"141}

Under the Criminal Code publication of a defamatory libel is a crime. ${ }^{142}$ In Canada, this charge is infrequent. Recently in England there has been much publicity over the efforts of Sir James Goldsmith to pursue the publishers of Private Eye through both criminal and civil proceedings. ${ }^{143}$ The prevailing view is that a defamed person should normally be left to

139. [1953] A.C. 420 at 443.

140. Id. at 451.

141. This part is based on Court files, reported judgments, and to a smaller extent, on the recollection of the writer who had some contact with these cases. In connection with the second case, he is indebted to Wm. Henkel, Q.C.. Assistant Deputy Attorney General and William Joyce, Manager, Records and Micrographics for making available the Attorney General's files.

142. Sections $264,265$.

143. Goldsmith v. Pressdram [1977] 2 All E.R. 557 (Q.B.D.), where leave to prosecute was granted; Goldsmith v.Sperrings [1977]2 All E.R.566 (C.A.), where an application to stay or dismiss the plaintiff's actions was dismissed; see also Spencer, "Criminal Libel - A Skeleton in the Cupboard" (1977) Crim. Law Rev. 382 and 465. 
his civil action. There may, however, be cases where the libel is particularly serious so that the person defamed wants to press charges. He becomes a "private prosecutor". Under the Code, consent of the provincial Attorney General to any indictment is required, but if he refuses to consent then the court has power to consent. ${ }^{144}$ In England, leave of a judge is required to a prosecution against the publisher of a newspaper, but the leave of the Attorney General is not required to any prosecution for criminal libel. ${ }^{145}$

On two occasions an Alberta judge had held that as a general rule the court would not give consent to a charge of defamatory libel after the Attorney General's refusal, because the Attorney General could always stay the proceedings. Thus the judge's consent would be futile and there would be an unseemly contest between the judicial and executive branches. ${ }^{146}$

When Social Credit came to power in 1935, the Alberta newspapers were generally, if not unanimously, hostile. The government decided to counter-attack. An Order in Council of September 22, 1937 authorized the Social Credit Board ${ }^{147}$ to publish literature informing the public how to realize the results of social credit. In charge of this programme were George Powell, a consultant brought from England, and Joseph Unwin, a member of the legislature. Powell sketched a leaflet lampooning political opponents. Unwin inserted the names of certain of those opponents. There was a dispute as to authorship, each man giving the major credit to the other. Unwin sent the leaflet to a commercial printer who made 20,000 copies and on September 28 sent them to the Social Credit League in Edmonton for distribution. Several thousand were circulated and the rest were seized under a search warrant dated October 2.

The leaflet had on one side the heading, "Bankers' Toadies". The nine men so designated were S.W. Field, H.H. Parlee, H.R. Milner, J.F. Lymburn, G.D. Hunt, L.Y. Cairns, G.W. Auxier, W.A. Griesbach and D.M. Duggan. All but Hunt and Duggan were well-known Edmonton lawyers, though Major General Griesbach was perhaps better known for his military record and political activity. The leaflet set out the affiliation of each of these men with the financial world or with the "Peoples (!) League". This was an organization opposed to Social Credit. Below the names was the exhortation: "EXTERMINATE THEM", followed by this remarkable non sequitur, "And to Prevent all Evasion, Demand the Result you Want $\$ 25.00$ A MONTH and a Lower Cost to Live". On the other side of the leaflet under the heading "Bankers' Toadies" were these words:

My child, you should never say harsh or unkind things about Bankers' Toadies. God made Bankers' Toadies, just as He made snakes, slugs, snails and other creepy-crawly, treacherous and poisonous things. Never therefore, abuse them - just exterminate them!

General Griesbach decided to lay a charge of criminal libel, and also seditious libel and counselling murder, though these were dropped. He retained Steer, who caused the search warrant to be issued. The complaints were laid on October 5 . The preliminary hearings were held separately

144. Criminal Code, s. 507 and s. 505(1)(b).

145. Gleaves v. Deakin [1979] 2 All E.R. 497 (H.L.).

146. R. v. Edwards [1919] 2 W.W.R. 600: Maloney v. Fildes [1933] 1 W.W.R. 33.

147. Established by the Alberta Social Credit Act, S.A. c.10, as am. S.A. 1937 (2nd sess.)c. 3. 
before Magistrate Harold Gibson. The evidence showed the authorship, printing and circulation of the leaflet. General Griesbach testified that he was incensed by the leaflet and thought it tended to divide the country. On cross-examination he was asked about his sense of humour and replied that it did not extend to amusement over the leaflet. Each of the accused was committed to trial and was granted bail.

On the arraignment before Ives J. on November 9, the agent of the Attorney General stated that the Attorney General (Premier Aberhart) would not prefer charges but would not obstruct the private prosecution. Since the Attorney General would not consent to the charges, Steer applied to Ives J. for consent. It was granted. Unwin selected trial by jury and Powell by judge alone. The evidence was similar in each case and largely a repetition of the evidence on the preliminary.

Unwin was defended by an able and respected criminal lawyer, Fred Jackson. The defence offered no evidence. The jury found Unwin guilty of publishing a criminal libel knowing it to be false. Mr. Justice Ives sentenced him to three months in prison. In Powell's case, the accused was defended by another experienced defense counsel, Hugh Calais Macdonald. Unwin was called by the Crown and Powell testified. Ives J. convicted Powell and sentenced him to six months in prison.

Both men appealed. Unwin was represented by Jackson's partner J.N. McDonald. Powell's counsel was N.D. Maclean as well as Macdonald. On February 7, 1938, Chief Justice Harvey for a unanimous court dismissed both appeals. ${ }^{148}$ Thereupon each of the accused went to jail though he was released after his sentence was half-served. The writer recalls that $\mathrm{Mr}$. Unwin received a vociferous welcome from his Social Credit colleagues when he returned to the House, and that Powell went back to England.

In the second case, ten years later, the persons alleged to have been libelled were the four members of the Child Welfare Commission of Alberta and in particular, Charles Hill, the Director. The charge came about in this way. Around the end of World War II, the Imperial Order of the Daughters of the Empire (I.O.D.E.) in Alberta had a sum of money remaining from their efforts to raise funds during the war. Interested in child welfare, they engaged Charlotte Whitton of Ottawa to advise them. Miss Whitton was an able, vigorous and outspoken person who later became a colourful Mayor of Ottawa. Coming to Alberta, she tried to obtain data from the Welfare officials in the government, with a view to recommendations to the I.O.D.E.. The government did not co-operate. She then wrote a lengthy report containing many severe criticisms of the administration of child welfare in the province. The report was made public in August, 1947. The government promptly appointed a Royal Commission to inquire into her charges. The members were Chief Justice Howson, Chairman and two District Court judges, E.B. Feir and J.W. McDonald. James Mahaffy, a Calgary lawyer, was counsel for the Commission while S. Bruce Smith and Horace Johnson represented the Child Welfare Branch. Steer apppeared for the I.O.D.E.. The Commission sat for months examining documents and briefs and hearing a large number of witnesses, including Miss Whitton. The evidence filled six thousand

148. R. v.Unwin[1938]1 W.W.R.339(App.Div.):R. v.Powell[1938]1 W.W.R.347(App.Div.). 
pages. The Commission made its report on December 3, 1948. ${ }^{148 \mathrm{~A}}$

In the meantime, a Toronto magazine called New Liberty came to the centre of the stage. The publisher was a wealthy young man named Jack Kent Cooke. (Later he went to the United States, obtained an Act of Congress making him a citizen, and acquired the Los Angeles Lakers basketball team, the Los Angeles Kings hockey team and the Forum where they play. ${ }^{199}$ A reporter named Harold Dingman wrote an article entitled "Babies for Export", based on Miss Whitton's report. He obtained her consent and that of the I.O.D.E. to quote from the report, and indeed sent to Miss Whitton the manuscript of his article.

It was published in the New Liberty for December 27, 1947, (appearing on the newstands twelve days earlier) accompanied by five drawings which showed pathetic mothers surrendering their babies and also showing the children being farmed out. The last of the five illustrations showed a disreputable-looking man dozing with a bottle beside him while two emaciated boys lifted a heavy log. (The artist, one Cahen, was to testify that it was a liquor bottle and that the man was "sleeping off a drunk".)

The article began:

One of the blackest and ugliest chapters in the development of modern governments has been written against the Province of Alberta. It is the unparalleled story of government trafficking in illegitimate babies exporting them to foreign homes; and the further story of unjustifiably harsh and delinquent care of Alberta's very young and very old. At these extremes of life, bureaucracy and tyranny rule.

This is followed by a laudatory description of Alberta and its people and then this:

Suddenly, out of this unique province has come the disturbing story of maladministration of child welfare, the absence of child protection, of baby exports to such distant points as California and South America and Alaska; of mothers pressured into giving up their babies before they even see them.

Then came a description of and extracts from Dr. Whitton's report.

The Howson Commission was sitting. On December 16 it had the Clerk of the Court at Edmonton send a wire to each of Cooke and Dingman "inviting" them to appear to show cause why they should not be committed for contempt. They declined. In addition, Mahaffy, as counsel for the Commission, asked the distributors of New Liberty in each of the cities of Edmonton, Calgary, Lethbridge and Medicine Hat not to distribute the issue. They wired Cooke for instructions. His wire in reply said: "We are prepared to distribute notwithstanding attempted ban. Proceed with distribution. We undertake to provide counsel and assume all expenses and fines." The Edmonton distributor, John Michaels, a prominent Edmonton businessman, nevertheless did not distribute the issue, but the other distributors did.

The Crown decided to lay a charge of defamatory libel. There was, however, a difficulty. A charge of libel could not be laid in Alberta because the alleged libellers resided, and New Liberty was published, outside that province. Accordingly the Crown charged Cooke with counselling John

148A. See Rook and Schnell, "Charlotte Whitton and the 'Babies for Export' Controversy of 1947-48" [1982] Winter Alberta History 11.

149. These details are set out in an article by Scott Young in the Globe and Mail, June 8, 1976, p. 35. A later note in the Edmonton Journal, of which the writer omitted to mark the date, says that Cooke had sold his Los Angeles interests and bought the Chrysler Building in New York. 
Michaels, the Edmonton distributor, to publish a libel. In addition the Crown charged Cooke, Whitton and Dingman with conspiracy to publish a libel. ${ }^{150}$

An Edmonton magistrate issued warrants for the arrest of Cooke and Dingman. The Criminal Code provides ${ }^{151}$ that where the accused is in another province, a magistrate in that province is obliged to endorse the warrant, whereupon it can be executed in that province. When the warrants were sent to Ontario for endorsement Cooke and Dingman applied in the High Court for an order prohibiting the endorsement. They were represented by Joseph Sedgwick and G. Arthur Martin, both of Toronto. J.R. Cartwright was one of the counsel for the Attorney General of Alberta. The applicants argued that the informations and warrants were defective. Their main contention, however, was that the accused should have been charged with the substantive offence of defamatory libel, which could have been done only in Ontario. Mr. Justice Barlow refused the application. ${ }^{152}$ Cooke and Dingman were not in fact arrested but came voluntarily to Edmonton. Miss Whitton had been given a summons and she too came.

The case attracted wide attention and feeling ran high as it had in the Bankers' Toadies case ten years before. The preliminary hearing began on January 27. It was held in the criminal courtroom in the Supreme Court House rather than in Magistrates Court. The Magistrate was Harold Hawe. Frawley and D.B. MacKenzie were for the Crown, Steer for Miss Whitton with S.H. McCuaig and Clarence Smith of Calgary (a brother of A.L. Smith) for Cooke and Dingman.

There is no need to describe the lengthy arguments over admissibility of various telegrams or the evidence of the persons connected with the publication and distribution of the article. (One witness was Roy Thomson who was Chairman of the board of New Liberty, and later became Lord Thomson of Fleet and the head of a large chain of newspapers.)

The notable feature of the preliminary was the decision of the Crown to call Steer as a witness in an endeavour to show Miss Whitton's complicity in the publication of the article. When he took the stand he was asked a question, put by MacKenzie: "Did your client Whitton give you any document purporting to be signed by Dingman?" Steer refused to answer. Martland appeared as his counsel and took the position that an answer would require a breach of Steer's obligation of confidentiality respecting communication with his client. There was considerable argument between Steer on the one hand and the Magistrate and Crown Counsel on the other. The latter submitted that an answer did not involve any breach of confidence; and the Magistrate pointed out that the question did not ask about conversations with or advice to Miss Whitton. Steer replied that he could not answer without revealing a professional confidence and "I do not propose to do it". The Magistrate then said "I think you can and I make the ruling that you answer the question as it was put to you" and: "Either you have to answer it or we will do something else." The hearing

150. Parliament promptly amended section 888 of the Criminal Code to say that the charge of conspiring to publish a defamatory libel must be tried in the province where the accused resides or where the newspaper is printed - see now section 421 .

151. Section 461 , formerly s. 662 .

152. R. v. Cooke and Dingman [1948] 2 D.L.R. 254 (Ont.). 
was then adjourned until the next day. After a Court reporter gave evidence from his notes of Miss Whitton's evidence before the Howson Commission, Frawley stated "There is no need to put further questions to Mr. Steer" and that the Crown's case was closed.

The three accused were committed to trial for conspiracy to publish a libel, and Cooke alone on the charge of counselling Michaels to publish a libel. Bail was granted. Milner was surety for Miss Whitton and Hugh Pearson, a prominent Edmonton business man, for the other two. Miss Whitton said she wanted to go to jail instead of being bailed but "on the advice of her counsel she changed her mind". ${ }^{153}$

The trial began on April 4 before Boyd McBride J. without a jury. Sedgwick came from Toronto to appear for Cooke and Dingman. McCuaig was with him. For the Crown were S.C. Blanchard of Calgary, Frawley and A.W. (Abe) Miller, an experienced Edmonton practitioner. The Crown wanted to proceed first with the counselling charge, which was against Cooke alone. Steer filed a notice of motion for an order that the conspiracy charge be heard first "on the ground that the accused Whitton should be heard on the question whether the words complained of are defamatory". The judge referred to the practice whereby charges are usually heard in the order in which the Crown sets them down, but held that in this case it would be unfair to the accused Whitton if the counselling charge were heard first and that the right asserted by the Crown was an infringement of the independence of the judge. ${ }^{154}$ Hence he ruled that the conspiracy charge must be tried first. Thereupon the Crown entered a stay of proceedings on that charge and proceeded against Cooke on the counselling charge.

The evidence was similar to that on the preliminary, and occupied four days. Boyd McBride J.gave judgment on 9 April 1948. The courtroom was packed. The writer recalls that immediately before the judge came into Court to give his verdict, Alfred Simpson, the Clerk of the Court and Sheriff, came into the courtroom and in a stern voice told those present (many of whom were leading members of the I.O.D.E.) that there must be no demonstration, whatever the verdict. The judge then entered the courtroom and delivered judgment. He explicitly refrained from detailed findings of fact and from declaring the principles of law applicable to them. The judgment is cryptic as to the reason for this though the writer conjectures that it was because of the existence of the Howson Commission. The judge set out four questions which he asked himself. Did the accused counsel John Michaels? If so, did he counsel Michaels to publish anything? If so was it defamatory? If so, was it without legal justification? Having put these questions he did not answer them one by one but simply pronounced the accused not guilty. ${ }^{155}$ Up to that point one could not tell what the judgment would be. It is reasonable to speculate that Sedgwick was prepared for a finding of guilty and had ready a plea as to sentence. In any case, he rose and said:

I must not thank a judge for having done his duty, but may I thank you for the great consideration you have given to the case and for your persistent kindness at times when I am sure I was a little tiresome; and my client asked me to say this to Your Lordship, regardless of the result, he wanted

153. Edmonton Journal, 31 January, 1948.

154. R. v. Cooke [1948] 1 W.W.R. 849 at $851-854$.

155. Id. 
to say himself that he had no intention at any time to embarass the Royal Commission that was sitting or to do any thing that would have reflected in any way on their conduct or on the conduct of the citizens of Alberta generally, and that, while it is not necessary for him to say anything, he would not like to leave this province with the feeling in the minds of the citizens that he did at any time intend to malign this province or its people.

The judge thanked Sedgwick and court was adjourned.

As mentioned earlier, the Howson Commission did not report until December 3, 1948..$^{156}$ The report says that the many accusations against the Child Welfare Branch turned the proceedings into a personal quarrel. The Commission found some of Miss Whitton's criticisms to be warranted. Others were directed against legislation and so irrelevant to the inquiry. The Commission made recommendations on adoptions, handling of neglected and delinquent children, foster homes and training schools and other topics. The report deals with Dr. Whitton's criticism of placement for adoption outside Canada and particularly in the United States. This is of course the subject that provided the title for the article in New Liberty. While the Commission recommended the discontinuance of cross-border placements, it rejected the suggestion of a "black market" or "traffic" in babies. "Not a shred of evidence was brought in to indicate that any Alberta child had been involved in a "black market' in babies." There had been no "traffic" in babies in the sense of something shady or illicit. The report does not refer to the article in New Liberty, which was of course an exaggeration of the Whitton report, but it says that the Whitton report itself contained "overstatement" and seemed intended to heap discredit on the Child Welfare Department.

\section{OIL AND GAS CASES: HEREIN BORYS AND TURTA}

The discovery of oil at Leduc in February 1947 marked the beginning of intensive exploration for oil and gas and also of large-scale production. However, there had been wells in Turner Valley as far back as 1914, a boom in 1929, and a flurry of activity after R.A. Brown, Sr. of Calgary brought in a well in South Turner Valley in 1936. These developments had produced regulatory statutes and some litigation. ${ }^{157}$

During World War II Steer was counsel for the plaintiff in Vulcan Brown Petroleum v. Mercury Oils. ${ }^{158}$ This was a dispute between the Brown interests and A.H. Mayland of Calgary. Mercury Oils was Mayland's company. His counsel was S.J. Helman. As a result of a "maze of transactions and documents", as Chief Justice Harvey put it, Mercury held an oil and gas lease and Vulcan Brown a sublease from Mercury. Vulcan covenanted to drill a well and then to drill a second well within twelve months after abandonment or completion of the first. The first well was completed on June 20,1938. Before the year was up an Order in Council under the Oil and Gas Wells Act forbade drilling within 440 yards of a producing well. Thus when Vulcan Brown applied to the Conservation Board for permission to drill the second well the application was refused.

156. Report of the Royal Commission appointed to Investigate Certain Charges, Allegations and Reports Relating to the Child Welfare Branch of the Department of Public Welfare, Section 11, at 49-54.

157. The validity of the Turner Valley Gas Conservation Act, S.A. $1932 \mathrm{c.} 6$ had been upheld as early as 1933 in Spooner Oils Ltd. v. A.G. Alberta [1933] S.C.R. 629. That Act and the Oil and Gas Wells Act, S.A. 1931 c. 46 were forerunners of today's Oil and Gas Conservation Act, R.S.A. 1980 c. $0-5$.

158. Mercury Oils v. Vulcan Brown Petroleums [1943] S.C.R. 37 affg. sub nom Vulcan Brown Petroleums v. Mercury Oils [1942] 1 W.W.R. 138 affg. [1941] 3 W.W.R. 384. 
In light of the failure to drill, Mercury claimed that Vulcan Brown had abandoned the sublease. Thereupon Vulcan Brown sued for a declaration that it was excused from drilling the well and that there was no abandonment of the sublease. The main issue was whether the plaintiff was relieved from its covenant to drill because of the "supervening illegality" produced by the Order in Council. Shepherd J. held that the covenant to drill was made in light of the law existing at the time and that a subsequent Order in Council rendering performance illegal operated to "repeal" the covenant.

The defendant appealed. Chief Justice Harvey would have allowed the appeal. Vulcan Brown could have provided against the effect of changes in the drilling regulations. The other four judges all agreed to dismiss the appeal but it is hard to put the reasons in a nutshell. They held there was no frustration of the sublease; it was still in existence. By implication the parties had agreed that Vulcan Brown should be relieved if the obligation to drill were rendered illegal, as it was.

Mercury appealed to the Supreme Court of Canada. The writer recalls that when Mr. Steer was preparing his factum he consulted John Weir, the Dean of Law and a close friend. This was in the spring of 1942, some three months before Dean Weir died. He was an authority on frustration of contracts and impossibility of performance.

The Supreme Court upheld the lower courts but took a somewhat different and more direct route. Steer had relied on a general rule that a party is relieved from his obligation by reason of supervening illegality. However the judgment simply referred to the lease and sublease and found the answer there. In the head lease Mercury had covenanted to abide by all statutes and regulations, and Vulcan Brown had covenanted to observe the head lease. Mercury could not complain that the plaintiff defaulted in not doing something contrary to the head lease and the sublease.

The Leduc discovery produced vigorous competition between oil companies in acquiring petroleum and natural gas rights. Just as in the case of a land boom, persons who had granted oil rights frequently wanted to escape the bargain in order to make a better deal. Since oil and gas leases often covered the grantor's homestead, the Dower Act came into play because an oil lease was a disposition under that Act and the wife's consent was necessary. If the consent were not acknowledged by the wife apart from her husband then the whole transaction was open to attack.

Six months after the discovery of oil in Leduc, a farmer named Pearson gave a petroleum and natural gas lease to one Reddick. Pearson was to receive $\$ 6000$ payable at the rate of $\$ 100$ a month. After he had accepted seven of these payments, he received an offer of a better deal. He alleged that the lease was void because he had been present when his wife signed the consent under the Dower Act and when the Commissioner for Oaths signed the acknowledgement. There was no pretence that the wife had been misled or did not know the nature of the transaction. Mr. Justice McLaurin accepted Steer's contention that the lease was void. ${ }^{159}$ Not long afterwards in another case with similar facts the Supreme Court of Canada found a way to uphold the lease by applying the curative section

159. Reddick v. Pearson [1948]2 W.W.R. 1144. 
in the Dower Act. It had not been invoked in Reddick. ${ }^{160}$

The Dower Act was completely recast in 1948 as these cases were in the courts. The new Act was designed to put an end to all the litigation over the Dower Act, but it failed in that object. The first important case under the new Act had nothing to do with a petroleum lease but had implications for such a lease, so the writer will describe it. It involved an agreement between Pinsky and Wass for exchange of homesteads. In it was an unusual "escape" clause. Pinsky brought action for rescission, invoking both the escape clause and non-compliance with the Dower Act. Wass counter-claimed for specific performance. Neil D. Maclean acted for Pinsky and Steer for Wass. The spouses had in fact signed the agreement but not the formal consent required by the Dower Act. The trial judge rejected the plaintiff's argument that non-compliance with the Act rendered the agreement void but he held that Pinsky was entitled to invoke the escape clause. Steer appealed. He won but the reasoning of the judges was remarkably diverse, leading Maclean to remark that the Appellate Division, like Gaul, was divided into three parts - not one of his more memorable utterances. Chief Justice 0'Connor in dissent declined to deal with the Dower Act. W.A. Macdonald and Clinton Ford JJ.A. held that non-compliance with the Dower Act makes an agreement invalid, but the latter held that Pinsky was estopped from raising the invalidity. Parlee and Frank Ford JJ.A. held non-compliance with the Dower Act does not render the agreement void. None but 0 'Connor C.J. would have applied the escape clause.

Pinsky appealed to the Supreme Court. He won, thanks to the escape clause. Two of the five judges thought as well that the agreement was voidable for non-compliance with the Dower Act. ${ }^{161}$

When the Canadian Pacific Railway built the first trans-Canada line, it received from Canada large grants of prairie land, including the minerals. At one time coal doubtless was of greater interest to the C.P.R than petroleum, but the Leduc discovery changed this. The company had land in many areas which produced oil and gas. In 1906 the C.P.R. had sold a quarter section of land near Leduc to one Borys. When the C.P.R. gave him a transfer in 1918 it reserved "coal, petroleum and valuable stone". It will be noted that the C.P.R.'s reservation did not specifically mention natural gas. Borys' son became registered owner in December 1947, ten months after the Leduc discovery. He contended that he owned the natural gas and that no one else could interfere with it. He brought action against the C.P.R. and also against Imperial Oil Limited which was lessee of the petroleum rights from the C.P.R.. ${ }^{162}$ Borys asked for a declaration that he owned the natural gas and for an injunction to restrain the defendants from removing it. Imperial's counterclaim asked for a declaration that it owned the gas, and alternatively that it was entitled to remove gas to the extent necessary to produce its petroleum. Steer was counsel for Borys' Calgary solicitors. Helman and R.R. Mitchell acted for the C.P.R.

160. McColl-Frontenac Oil Co. v. Hamilton [1953] 1 S.C.R. 127.

161. Pinsky v. Wass [1953] 1 S.C.R. 399, revg. 2 W.W.R. (N.S.) 47 and restoring [1950] 2 W.W.R. 1278. The later cases on the Dower Act are not part of this narrative; see Meduk v.Soja [1958] S.C.R.167;Senstad v.Makus [1978]2 S.C.R.44;McFarland v. Hauser[1979] 1 S.C.R. 337.

162. Borys v. C.P.R. [1953] A.C. 217 , affg. 4 W.W.R. (N.S.) 481, revg., in part, 2 W.W.R. (N.S.) 145. 
while Nolan and Chambers appeared for Imperial Oil. Chief Justice Howson listened to an array of experts on both sides as to whether "petroleum" includes natural gas. Then after examining definitions he concluded that petroleum means crude oil and does not include natural gas. In the Leduc field some gas was separate from the petroleum and in a "gas cap" above it, while some was in solution in the petroleum. It acted as a "lifting agent". Howson C.J. held that the defendants had no right to possess and use the natural gas at the plaintiff's expense.

On the defendant's appeal, W.A. Macdonald J.A. agreed with the trial judge. Parlee J.A., speaking for the other four judges, agreed that petroleum and natural gas were different substances but held that the reservation of petroleum in favour of the C.P.R. meant petroleum in place underground so that natural gas in solution is included; and further that the reservation meant that the defendants could extract the petroleum provided it were done in a reasonable manner, even if it interfered with and wasted the plaintiff's gas. The reservation of petroleum implied the right to recover it. Thus Imperial succeeded on its alternative counterclaim.

Borys appealed to the Privy Council. The respondents cross-appealed the ruling that gas in the gas-cap was not included in petroleum. The argument occupied eight days in July, 1953 and judgment was delivered the following January. In essence the Judicial Committee agreed with the Appellate Division in its reasons and dismissed the appeal and crossappeal. This was the last of Steer's five appearances before the Privy Council. The writer's recollection is that the Wimbledon tennis championships were being played at the time and that Steer was able to attend some of the matches through the help of $\mathrm{Mr}$. Theobald Mathew of Charles Russell and Company, Steer's London solicitors.

Before Borys reached the Judicial Committee, Turta v. C.P.R. ${ }^{163}$ was in the Alberta courts. When Alberta became a province it enacted its own Land Titles Act on the lines of the federal legislation that had been in effect in the Northwest Territories since 1886. A Land Titles office was established at Edmonton and another at Calgary. From time to time the Registrar made mistakes. Subsequently they were discovered. In the case of mistakes relating to ownership of oil and gas, some turned out to be costly. The consequences might not have been so serious had the Assurance Fund been adequate, but the Land Titles Act gave miserly compensation to a person who lost his minerals through the Registrar's error.

The land involved in the Turta action was close to the discovery well at Leduc. In 1901 the C.P.R. had acquired title to both surface and minerals. In 1908 it transferred the land to one Podgorny, reserving coal and petroleum. The new title in Podgorny's name should have conformed to the transfer. However, the Registrar made a mistake and reserved only the coal. The consequence was that Podgorny's title showed him as owning the petroleum. By 1918 Anton Turta was owner of the quarter section, having purchased it. A farmer who did not speak English, he never thought of the minerals but the fact is that the title gave him the petroleum.

163. C.P.R. v. Turta[1954]S.C.R. 427 affg. sub nom. Turta v. C.P.R. 8 W.W.R.(N.S.) 609, affg. 5 W.W.R. (N.S.) 529. 
During World War II, the Registrar, concerned about the errors, made a special effort to correct them. On January 16th, 1943 he altered Turta's certificate of title to show that petroleum as well as coal was reserved to the C.P.R. and at the same time he purported to restore the C.P.R.'s title to the petroleum. Neither Turta nor the C.P.R. knew of the alterations. In the following year Turta transferred one-half of the parcel to each of his two sons and of course their titles! showed the reservation of coal and petroleum. At this point Turta owned nothing so far as the register showed.

Whenever there is a "play" for mineral rights, the interested companies search the title of land in the area. In the five or so years after the Leduc discovery the Land Titles Office in Edmonton was a bedlam. Imperial Oil was of course active. In 1946 it had acquired from C.P.R. an option to lease the oil under the Turta land. Right after the Leduc discovery a solicitor for Imperial Oil made an historical search of the title and discovered the original mistake and its purported correction. The actual lease from the C.P.R. to Imperial Oil was made on March 6th, 1951, after Turta had asserted his claim to the petroleum. He had consulted Steer in March 1950. In essence his claim was that he obtained title as a bona fide purchaser in 1918. Since the title did not exclude the petroleum, he became owner of it and nothing in the subsequent events deprived him of that ownership. The C.P.R. of course argued that it had never been deprived of ownership. The case raised fundamental questions as to the basic principles of Alberta's Land Titles Act. Was Turta entitled to "rely on the register" even though he had never looked at it and never intended to acquire the minerals? Was the Registrar entitled to make the corrections in 1943? Could the C.P.R. invoke those provisions in the Land Titles Act which create exceptions to indefeasibility of the current title specifically, misdescription and prior certificate of title? There was a subsidiary question as to whether, assuming Turta had a cause of action, he had delayed too long in bringing it, and conversely Turta argued that, even if the C.P.R. owned the petroleum, he had acquired title by possession of the petroleum for over ten years. Neither assertion under the Limitations Act played a part in the ultimate result.

The trial judge Mr. Justice Egbert analysed the facts and the law in the utmost detail in a long judgment. He held that the purported corrections, though they would have been good as between the C.P.R. and Podgorny, were a nullity as against Turta because he was a bona fide purchaser. He was entitled to rely on the state of the title when he acquired the land. The C.P.R. relied heavily on the two exceptions to indefeasibility mentioned above - prior certificate of title and misdescription. Egbert J. held that the first exception comes into play only when there are two certificates of title in existence at the same time. Here the C.P.R. title had long been cancelled and the purported correction did not restore it. As to misdescription, Egbert J. gave it a narrow interpretation. It applied only where the title includes a parcel that was not intended to be transferred and there was no such situation here.

In essence the Court of Appeal agreed with the trial judge, though Chief Justice O'Connor did so with regret. Mr. Justice Clinton Ford dissented on the ground that the C.P.R. had a prior certificate of title. It had never been properly cancelled. 
On a further appeal to the Supreme Court of Canada, a majority of six judges to three sustained the judgments below. The dissenters thought that Turta had acquired title to the petroleum by misdescription. Petroleum came within the definition of land and the petroleum was a different parcel from the surface so the exception as to misdescription applied and the fact that Turta was a bona fide purchaser from Podgorny made no difference. The majority in essence agreed with the courts below.

The significance of the decision (quite apart from the fact that one party lost the minerals and another one acquired them through a "million dollar mistake" in the Registrar's office) is that it does a great deal to strengthen the notion that "the title is everything". A serious criticism of the law as it stood at the time was that the assurance fund was liable for only the amount laid out for the minerals and a further sum not exceeding $\$ 5000 .{ }^{164}$ After the Supreme Court's decision, the government asked the Benchers of the Law Society to establish a committee to make recommendations. The committee made a report and in 1958 a new provision allowing more liberal compensation was enacted. ${ }^{165} \mathrm{It}$ is the present section 176(1). Also in 1958 the Mineral Interests Compensation Act ${ }^{166}$ provided for recovery of damages for old mistakes on the same basis as that provided by section 176(1), with a three-year time limit from April 1, 1958 for bringing action against the Registrar.

One point that emerges clearly from Turta is that he succeeded because he was a bona fide purchaser. Had he received the land as a gift, he would have failed. ${ }^{167}$

A difficult problem that has come up in cases like these is the effect, if any, of the Statute of Limitations. It is now clear that the action for a simple declaration of title by the person whose title had been taken from him by the Registrar's unauthorized act is not one for possession and is therefore not affected by the ten-year time limit in the Limitations Act. ${ }^{168}$ Alternatively, there is a completely different question that can arise: is it ever possible for a person to possess minerals so that after ten years he will have acquired ownership by possession as against the registered owner, as is possible in the case of the surface? The case that deals most directly with this question is Duncan v. Joslin. ${ }^{169}$ In that case Steer acted for the plaintiff, whose claim was basically the same as that of Turta. Thus he was held entitled to the minerals. However the defendant had, through the Registrar's error, been registered as owner of the minerals, paid the mineral tax and given an oil and gas lease to an oil company which had carried out seismic surveys. The defendant argued that on these facts he had possession of the minerals and that such possession had extended over a ten-year period so that therefore he had acquired possessory title under the Limitations Act. Mr. Justice Porter was not sure that a fugacious mineral could be possessed, short of actual physical control, and in any event the acts relied on by the defendant did not support a claim of

164. S.A. 1949 c. 56 s. 5: R.S.A. 1955 c. 170 s. $176(1)$.

165. S.A. 1958 c. 34 s. 10.

166. S.A. 1958 c. 43.

167. Kaup v. Imperial Oil Limited [1962] S.C.R. 170.

168. See Re Pogue and Lane (1951) 3 W.W.R. (N.S.) 97, in which Steer was successful and C.P.R. v. Turta [1954] S.C.R. 427 at 449, 450 per Estey J; see also supra n. 167.

169. (1965) 51 W.W.R. 346. 
adverse possession. Mr. Justice Kane and Mr. Justice Macdonald examined the facts to determine whether the defendant had acquired possession of the minerals and concluded that he had not. The defendant failed to prove that he was in exclusive, open, or visible and notorious possession for ten years.

Another case arising out of the discovery of the Leduc field is Cotter v. General Petroleums. ${ }^{170}$ Cotter held a petroleum and natural gas lease in the Leduc field and gave the defendant an option for a sublease, exercisable by August 1st, 1948 by drilling a well. The agreement went further in that the defendant covenanted to exercise the option. In view of dry holes nearby, the defendant did not drill. The plaintiff sued for breach of the covenant to drill. Steer was not on the trial, where McLaurin J. held that the defendant broke the covenant. This left a very difficult question as to the amount of damages the plaintiff suffered from the defendant's failure to drill. Cost of drilling would have been $\$ 53,000$. The plaintiff claimed this sum and in addition some $\$ 45,000$ for loss of the chance to discover oil. McLaurin J. fixed the damages at the cost of drilling. On the appeal the defendant retained Steer. Chief Justice Harvey, at the age of 86 , presided. This was some three months before his death in the fall of 1949. Steer's main argument, one which had not been raised at the trial, was that the covenant to drill was repugnant to the option and therefore must be ignored. The Court of Appeal accepted this argument and so the action was dismissed. The plaintiff appealed to the Supreme Court. Only one judge, Locke J., agreed with the Appellate Division. The majority held that there was no repugnancy between the option and the covenant. They must be read together and the result was that the defendant had covenanted to drill. However, the plaintiff was not entitled to damages equal to the cost of drilling a well, but only to the $\$ 1,000$ he had paid to preserve the head lease. This result was the next thing to a win for Steer, but the writer's recollection is that he was just as dissatisfied as though his client had been required to pay the amount awarded at trial.

A case which might not have great legal significance but in which important holdings were at stake is Perry v. Harvey. ${ }^{171}$ Harvey held eight Crown leases of petroleum and natural gas rights in the area west of Westaskiwin. After lengthy negotiations, Perry thought that he had a contract with Harvey to buy the leases, but Harvey withdrew. Steer acted for Perry in his action for specific performance. He won in the Alberta courts, but in the Supreme Court, the appellant's counsel, J.J. Robinette of Toronto, persuaded the court that there was no contract.

In the post-Leduc era, a number of oil and gas cases have dealt with this situation: the owner of the minerals gives an oil and gas lease for one year. The lessee covenants to drill within the year. However, if he does not do so he may extend the lease for another year by paying $\$ 1.00$ an acre before the year has expired. The payment is called a "delay rental". Let us assume that at the end of the first year, the lessee (an oil company) wants to extend the lease but is late in making the payment even by one day. The company argues there is a "forfeiture" and invokes the provision in the Judicature Act ${ }^{172}$ which empowers the Court to relieve against

170. [1951] S.C.R. 154 revg. [1949] 2 W.W.R. (App. Div.) and restoring except as to quantum [1949] 1 W.W.R. 193.

171. [1953] 1 S.C.R. 233 revg. 4 W.W.R. (N.S.) 660 (A pp. Div.).

172. R.S.A. 1980 c. J-1 s. 10. 
forfeitures. The landowner argues that there is no forfeiture at all but that the lease simply came to an end when the payment required to extend the lease was not made in time.

This was the basic situation in East Crest Oil Company v. Strohschein. ${ }^{173}$ Steer acted for the owner of the land. The oil company failed to pay the "delay rental" due on September 13th, 1950, so the farmer contended that the lease was terminated. The oil company stated that the failure to pay was due simply to an oversight and tendered the payment, relying on a clause which permitted the lessee to remedy a default within 90 days. The tender was refused. Both the trial judge and the Appellate Division held that there was no default or forfeiture and that the lease was simply at an end. The trial judge said "defendant's counsel [Steer] with some force chose to put the plaintiff in the position of having no more than an option to drill for oil and, having failed to protect his position by making the payment of the delay rental on its due date, the option lapsed". In essence both courts accepted this argument.

Some thirteen years later in Superior Oil Limited v. Kanstrup ${ }^{174}$ Steer acted for Superior, the lessee. It drilled a gas well not on the leased land but on pooled land, and capped it because there was no market. The ten year term of the lease expired soon after. Superior argued that the drilling of the well preserved the lease, and that in any case payment of the "shut-in" royalty of $\$ 100$, payable under the lease where gas from a producing well was not sold or used, was only a week late so that the lease was still in existence. The trial judge, the Appellate Division and Supreme Court all ruled against the lessee. On the difficult question of construing the lease, and an amendment providing for pooling, Martland J. for an unanimous court held that the existence of the capped well off the leased land but on the pooled land did not operate to keep the lease alive; and even if it did, Superior did not pay the royalty until a week after expiration of the lease, so Strohschein applied.

Another case involving minerals raised an intriguing point. After World War I an ex-serviceman named Jardine acquired from the Soldier Settlement Board the title to a farm in 1928. Minerals were excluded. He willed all his property to his wife and made her executor. He died in 1938 and she died in 1949, with a will making Royal Trust Company her executor. Around that time the S.S.B. decided to make the minerals available to soldier settlers. The Royal Trust Company, representing Jardine's estate, took up the offer and acquired the minerals. The question then was - did the minerals go to Mrs. Jardine under her husband's will, or did Jardine die intestate as to the minerals? Steer argued that they went with the land - that they were grafted on to the surface or an accretion to it. This argument failed, so the minerals went to the next of kin and not under Jardine's will. ${ }^{175} \mathrm{~A}$ similar point came up later on an appeal from Saskatchewan where the mineral rights had been forfeited before the making of a gift of the land and were later restored to the estate. The Supreme Court of Canada held the minerals did not follow the gift. It included only what the donor held at the time, namely the surface. ${ }^{176}$ More

173. (1951) 4 W.W.R. (N.S.) 70 and 553 (App. Div.).

174. Superior Oil v. Kanstrup [1965] S.C.R. 92 affg. 47 W.W.R. 129, affg. 39 D.L.R. (2d) 275.

175. Re Jardine (1955) 17 W.W.R. 197 (App. Div.).

176. Blackmer v. Guaranty Trust Company (1972) 28 D.L.R. (3rd) 215 (S.C.C.). 
recently, the same basic problem arose again in Alberta in Re Timms, and with the same result. ${ }^{177}$

A nother unsuccessful effort to secure minerals for the owner of the surface occurred in Reese v. The Queen. ${ }^{178}$ Steer was counsel for the Brownlee firm for the petitioners. They were soldier settlers on land which had been an Indian reserve near Ponoka. The Board's solicitor told them they could acquire the minerals, but in fact an act of 1919 passed before they bought the land excluded minerals. The judgment held that nothing had occurred to vest the minerals in the petitioners, so they failed.

\section{UTILITIES CASES}

In 1957 Steer appeared in a British Columbia case, Prince George v. Inland Natural Gas Co.

West Coast Transmission Company had been granted the right by the federal Energy Board to build a natural gas pipeline from a field in the Peace River country in Alberta through British Columbia and on into the United States at a point near Vancouver. Inland Natural Gas Company had permission from the B.C. government to build tributary lines to points in the interior of British Columbia. Both Inland and the Prince George Gas Company wanted to construct a five-mile spur line from West Coast's pipeline into Prince George and to supply that city with gas. Lengthy hearings were held before the Public Utilities Commission. Steer acted along with two British Columbia counsel on behalf of Prince George and the Prince George Gas Company. Inland was successful before the Commission. Prince George made an effort before the Court of Appeal to obtain leave to introduce further evidence but this failed. ${ }^{179}$ Then, on the appeal on the merits, the appeal succeeded in a 2-1 judgment. The court had to deal with intricate statutory provisions, a complicated order of the Commission, the economic factors and constitutional questions. O'Halloran J.A., one of the majority, clearly thought that the order of the Commission was unfair to Prince George Gas Company. ${ }^{180}$

Some two years later a contest occurred in a rate case. ${ }^{181}$ It involved the City of Edmonton and three other municipalities against Northwestern Utilities Ltd.. The Public Utilities Board had applied in Northwestern's favour an amendment which permitted it in fixing rates to consider the effect of undue delay in the hearing. Moreover, it had ruled that the company could change its rates to reflect the increased cost of purchased gas. The municipalities were given permission to appeal, over Steer's objection that there was no question of jurisdiction or law but merely one of fact. On the appeal, three of the five judges held that the amendment applied to an existing application, while all of them held that the Board could not take into consideration the increased cost of purchased gas. ${ }^{182}$ Each

177. Unreported, 16 October 1975, J.D. of Edmonton, S.C. 89545 (Alta. S.C. T.D., Bowen J.); affd. unreported, 24 February 1977, S.C. 10689 (Alta. S.C. A.D.).

178. [1957] S.C.R. 794, affg. [1956] Ex. C.R. 94.

179. (1957) 9 D.L.R. (2d) 47 (C.A.).

180. (1958) 14 D.L.R. (2d) 247 (C.A.).

181. Edmontom, Jasper Place, Red Deer \& Vegreville v. Northwestern Utilities (1959) 29 W.W.R. 457.

182. (No. 2), (1960) 34 W.W.R. 241 (App. Div.). 
side appealed. Steer succeeded on both issues. ${ }^{183}$

The last important utilities case is Canadian Western Natural Gas Company v. Central Gas Utilities. ${ }^{184}$ Central was a small company which distributed propane at Vulcan. In 1953 it needed financial assistance and obtained it from International Utilities, the parent company of Canadian Western, with which Milner had long been associated. In the succeeding years International gave further financial help to Central. By 1958, when natural gas became available, Canadian Western offered to buy the Vulcan operation from Central. Central's shareholders agreed, with International's vote in support, though there was vigorous opposition. The Public Utilities Commission approved the sale and Canadian Western obtained a franchise from the town of Vulcan for the distribution of natural gas. Central and its subsidiary thereupon sued Canadian Western, International Utilities and Messrs. Milner and Maybin (an officer of Canadian Western) for (a) conspiracy to destroy competition and (b) for a declaration that Canadian Western held the franchise in trust for Central. W.A. McGillivray, who is now the Chief Justice of Alberta, was for the plaintiffs. Steer appeared for the defendants, and his son, Cameron, was with him. Both claims failed before Milvain J..

On appeal, the Appellate Division agreed that no conspiracy had been proved, but in a 2-1 judgment found Canadian Western to be in a fiduciary position towards Central so that Canadian Western held its franchise as trustee for Central.

Canadian Western appealed to the Supreme Court of Canada. A unanimous court held that International had carried Central through many years of financial difficulty, and that in its dealings with the town of Vulcan, Canadian Western was not in a fiduciary position towards Central.

\section{TAX CASES}

Steer was always alert to see that his client was not fixed with a tax that should not have been imposed. Many problems arose under the Succession Duty Act, the Corporations Taxation Act ${ }^{185}$ and the Unearned Increment Tax Act. ${ }^{186}$ These did not reach the stage of litigation so far as the writer is aware.

The first reported tax case is Great West Garment Company v. $M . N . R . .^{187}$ In 1941 the company fixed its officers' salaries at various amounts free of income tax. In 1942 a Salaries Order forbade an increase in salary rates. The income tax rates were increased in 1942 and 1943 so the amount payable to the officers went up accordingly. The M.N.R. alleged that this was a forbidden bonus. Steer appeared for the company. Gerald O'Connor J. rejected the Minister's argument. The salary was increased, but not the rate. Moreover the employer did not bring about the increase; it was the Income Tax Act that did so.

183. [1961] S.C.R. 392.

184. [1966] S.C.R. 630, revg. (1965) 53 W.W.R. 705 (App. Div.) and restoring (1965) 49 W.W.R. 513.

185. Both repealed S.A. 1962 c. 86.

186. Repealed S.A. 1956 c. 57.

187. [1947] Ex. C.R. 458. 
The next income tax case had to do with the estate of Senator Patrick Burns of Calgary who had died in $1937 .{ }^{188}$ His will had directed payment of 60 per cent of the income of his trust estate to named individuals and 40 per cent to be accumulated for the lifetime of his daughter-in-law and added to the corpus of the trust estate. On her death the corpus was to be distributed -67 per cent to named individuals and 33 per cent to the Royal Trust Company for the Burns Memorial Trust. The beneficiaries of the trust were five charities - the Lacombe Home at Midnapore, the Salvation Army at Calgary, a children's shelter in Calgary, the families of Calgary firemen and the families of Calgary policemen. The last three were not yet in existence as charitable institutions.

Not long afterwards the Minister of National Revenue claimed income tax in respect of the income that was accumulating for the benefit of the Burns Memorial Trust: Acting for the Royal Trust Company, Steer argued that the Burns Memorial Trust was a charitable institution and so the income was exempt. He failed in the Exchequer Court on the ground that the accumulated income did not accrue to the Trust.

The executors and the Royal Trust Company appealed to the Supreme Court of Canada. They won a partial victory when the Court held that the proportions of the income to go to the Lacombe Home and the Salvation Army were free of income tax for 1938 and 1939 because there was no adequate charging section applicable to them for those years. On a further appeal to the Privy Council, Steer did not appear. H.G. Nolan represented the appellants. The final judgment upheld the Supreme Court, with the variation that the Lacombe Home and the Salvation Army had an exemption for 1940 as well as for the two previous years.

Parenthetically, we shall mention here another issue that arose in connection with the same will. ${ }^{189}$ In 1958, at the expiration of twenty-one years from the death of Senator Burns, the daughter-in-law was still alive. Assuming the Accumulations Act of Great Britain to be in force in Alberta, then income after the expiration of the twenty-one years had to be "released". The difficult question in such a case is - to whom is it released? Steer for the Royal Trust Company argued that his client should receive 33 per cent of the income for the Burns Memorial Trust because 33 per cent of the corpus was ultimately to go to that trust for the five charities. The trial judge directed that all the released income should go as on intestacy. ${ }^{190}$

On appeal the Appellate Division held that since the testator had shown a general charitable purpose in the gift of 33 per cent of the corpus, then 33 per cent of the released income should be distributed for charitable purposes pursuant to a scheme to be approved by the Court. In a notable dissent, Porter J.A. held that the Accumulations Act was not in force in Alberta. ${ }^{191}$

188. Burns' Executors v. M.N.R. [1950]2 W.W.R. 1290 (P.C.) revg. in part [1947] S.C.R. 132 revg. in part [1946] Ex. C.R. 229.

189. Both before and after Senator Burns's death Steer appeared on a number of applications relating to the Senator's estate. Not all are reported.

190. Legislation on these bequests: The Burns Memorial Trust Act, S.A. 1956 c. 64, as am. S.A. 1981 (Bill PR 12); The Honourable Patrick Burns Settlement Act, S.A. 1975 (2nd sess.) c. 91, as am. S.A. 1981 (Bills PR 2,11).

191. Re Burns Estate (1960) 32 W.W.R. 689 (App. Div.), revg. in part 26 W.W.R. 49. The Perpetuities Act, S.A. 1972 c. 121, declared that the Accumulations Act does not apply in Alberta. 
Returning to income tax cases, Noak v.M.N.R. ${ }^{192}$ raised the old problem whether a gain on the purchase and sale of property is income or capital. Miss Noak had worked all her life but over the years made a substantial number of investments, including the purchase of houses which she later sold. Rejecting Steer's argument that the profits were capital gains, the Supreme Court found that Miss Noak's main intention was to make profit on resale so the profit was income.

The last case, Lethbridge Collieries v. The King, ${ }^{193}$ is not strictly a tax case. During World War II the federal government was concerned to keep coal mines in production. In 1942 an Order in Council provided for a subsidy of 35 cents a ton in the Lethbridge area. The company took this as a firm offer and acted accordingly but never received more than 16 cents a ton. It brought a petition of right claiming the difference. Steer represented the coal company. Gerald 0 'Connor J. thought that it was "entitled" to the full subsidy but went on to say that there was no legal liability enforceable by petition of right. Steer argued that there was a "statutory contract" and as an alternative, that the Crown had made an offer which the company had accepted by producing the coal. This argument failed. The company appealed to the Supreme Court which affirmed the trial judge. There was no firm offer to pay 35 cents a ton. The documents announcing the subsidy made it clear that payment was not to be automatic. The board made no order for payment of a subsidy having the force of law, even if it had power so to do.

\section{THE LAST SUPREME COURT CASE}

Throughout the fifties Steer had a number of appeals in the Supreme Court of Canada, as already described. Then there was a concentration of appeals in the mid-sixties. In addition to Kanstrup, Superstein and Central Gas, which have been noted, there were three others.

In each of the first two Steer appeared for the plaintiff/appellant and succeeded. One was an action on a guarantee. ${ }^{194}$ The other was a claim to the proceeds of the sale of almost four hundred head of cattle. ${ }^{195}$ In the third case, the Alberta courts had ruled that William Hawrelak was ineligible as Mayor of Edmonton because he held 40 per cent of the shares of a company which had sold land to the City. ${ }^{196}$ Steer joined J.W.K. Shortreed as counsel for the appellant. The appeal was dismissed in a fiveline judgment.

After the six cases in the mid-sixties Steer did not appear again in the Supreme Court until his last case, Walker \& Clark v. The Queen, which was argued in October $1969 .{ }^{197}$ It dealt with the right of lessees in Jasper National Park to renew their leases. In 1962 the Government had amended the National Parks General Regulations to restrict the right of renewal contained in leases. The lessees formed an association to protect

192. [1953] 2 S.C.R. 137 affg. [1952] Ex. C.R. 20

193. [1951] S.C.R. 138 affg. [1950] Ex. C.R. 1.

194. Weldwood-Westply v. Cundy [1965] S.C.R. 586.

195. Hurly v. Bank of Nova Scotia [1966] S.C.R. 83, revg. 52 W.W.R. 513 (App. Div.).

196. Hawrelak v. The Queen (1966) 55 W.W.R. 320 (S.C.C.), affg. sub nom R. v. Hawrelak 53 W.W.R. 257 (App. Div.).

197. The writer is indebted to Prof. Walter Mis, who appeared with Steer in the Exchequer Court for assistance in connection with this case. 
their interests, and retained Steer. (His cottage on Lake Edith was near the townsite of Jasper.) It was necessary to scrutinize a large number of leases to select two that would provide the strongest test case. Walker's lease was of a cottage lot on Lake Edith, while that of M.E. Clark \& Son Ltd. was of a commercial lot in the Townsite of Jasper. Granted in 1924 and 1925, respectively, they were for 42 years. Each lease had two renewal clauses - one said that if the parties could not agree on the amount of rent on renewal, it would be fixed by arbitration. The other said that, assuming the lessee had observed the terms of the lease, he could obtain the renewal with the same renewal provisions that were in the original lease. In other words, the leases gave a right of perpetual renewal to the lessees.

As the leases were about to expire, each lessee, having observed the terms of the lease, applied in proper time for a renewal. The Crown was prepared to grant one renewal of 42 years, but no more. Each lessee refused to accept this offer but insisted on a new lease containing the same right of renewal as was in the original lease. Each brought a petition of right in the Exchequer Court for a declaration of the right of renewal.

The issue required examination of seven Acts of Parliament and their amendments, and of the Act of the Imperial Parliament confirming the transfer of natural resources to the prairie provinces in 1930, and of the Alberta Land Titles Act. It also called for scrutiny of twelve Orders in Council dealing with National Parks and Forest Reserves, and of five more dealing with Jasper National Park. ${ }^{198}$

The first question was difficult - what was the authority for the original leases? There were regulations of 1909/11 covering National Parks and regulations of 1913 covering Forest Reserves. The leases themselves appeared to have been drawn in the light of the 1913 regulations. Steer argued that they applied. It was to his interest so to do because the 1913 regulations provided a stronger case for authorization of the right of perpetual renewal. The trial judge held for the Crown on this question. The 1909/11 regulations authorized leases "for any term not exceeding 42 years with the right of renewal". The Crown argued that this did not mean "right of perpetual renewal". Gibson J., however, held that it did.

The Crown then argued that nonetheless the renewal clauses were of no effect because Parliament had taken away the right of perpetual renewal by subsequent legislation and regulations; that the regulations of 1962 in force when the petitions were brought did not permit a perpetual renewal and that the leases in question were subject to the current regulations. Gibson J. answered this by quoting section 36 of the Interpretation Act which said that repeal of an enactment does not affect rights acquired under the repealed enactment.

The Crown next argued that the leases themselves said that they were subject to regulations from time to time in force "for the control and management of Dominion Parks". Gibson J. agreed with Steer's argument that this referred only to general police regulations in the Parks and did not apply to the regulations empowering the Minister to grant leases.

198. See Walker \& Clark v. The Queen [1969] 1 Ex. C.R. 419 at 438-440, where the statutes and Orders in Council are listed. 
In the result Steer won at trial, save that the trial judge ruled that the clause in the original leases providing for settlement of rent on renewal by arbitration was of no effect because there was no authority for it in statute or regulation.

The Crown appealed to the Supreme Court of Canada, and the petitioners applied to vary the trial judgment insofar as it held the provision for settlement of rent on renewal by arbitration to be ineffective. On the argument before the Supreme Court, the Crown repeated its two main contentions in the court below:

(1) The regulations never did empower the Minister to grant leases renewable in perpetuity at the lessee's option;

(2) Even if they did, the current National Parks Act and regulations thereunder forbade the grant of leases with a provision for perpetual renewal.

Speaking for six of the nine judges, Martland J. reviewed the legislation prior to the time when the original leases were granted, and then reviewed the regulations. He held, contrary to the trial judgment, that the terms of the leases showed that the Crown had in mind the 1913 regulations rather than those of $1909 / 1911$, and further that those regulations permitted the leases in dispute and that the Crown could not impugn its own grants. Moreover the clause providing for arbitration to settle the amount of the rent on renewal was not invalid.

On the second argument, the Crown contended that the National Parks Act of 1930 and the regulations thereunder forbade the issue of leases with a covenant for perpetual renewal. Martland J. held that in the absence of clear statutory provisions enabling the Crown to escape its contracts, it was bound by them. The subsequent legislation and regulations did not operate to remove the Minister's authority to grant a renewal pursuant to the original lease.

Then the Crown argued that the leases themselves said that they were subject to the Parks Regulations. This argument was based on the provision in each lease that it was subject to regulations "now in force, or which may hereafter be made from time to time in that behalf". Martland J. upheld the ruling of the trial judge that this did not apply to regulations respecting leases.

Abbott and Judson JJ. in dissent thought that the 1909/1911 Regulations applied rather than those of 1913 and that they did not authorize leases with a right of perpetual renewal. Pigeon J. agreed with the trial judge. ${ }^{199}$

Shortly after this decision Steer retired. Though confined to his home, he retained a close interest in legal matters until his death in 1975.

\section{CONTRIBUTION TO LEGAL EDUCATION}

While still under articles in Edmonton, Steer for five months had taught in the night class of the Edmonton Public Schools three nights a week, one and one-half hours per night. This was a prelude to his many years in part-time teaching of law students.

199. R. v. Walker \& Clark [1970] S.C.R. 649 varying sub nom Walker \& Clark v. The Queen [1969] 1 Ex. C.R. 419. 
Under the Legal Profession Act, 1907, the Benchers had the responsibility of setting exams for articled students. ${ }^{200} \mathrm{However}$, the University of Alberta had a role in the instruction of students-at-law. Dr. H. M. Tory, the first president, thought that the University should conduct examinations and appoint examiners for the professional societies. So it was that a new University Act of 1910 empowered the Senate to make arrangements for those purposes with the Law Society and with other professional associations. ${ }^{201} \mathrm{An}$ agreement with the Law Society was made in $1912 .^{202}$ It provided that the University would conduct the examinations of articled students and would select the examiners, with the Law Society's approval.

This did not end the University's involvement in legal education. Although there was no Faculty of Law until 1921, the University in fact of fered an LL.B. degree. An articled student could enrol for the degree. To obtain it he or she had to take and pass extra courses over a four year period. Lectures for the articled students and those for LL.B candidates were given in Calgary as well as in Edmonton. They were usually in the Court House with barristers and some judges as lecturers. Steer became one of these lecturers shortly after he was admitted to the Bar. The University calendar for 1917-18 shows him as a lecturer in History of English Law and English Constitutional History.

By 1921 both the Law Society and the University wanted a Faculty of Law - one that would provide a three-year full-time course with at least some full-time professors. In contemplation of this the Legal Profession Act was amended in 1921 to provide for admission of graduates of the proposed new course, provided they spent a year under articles. ${ }^{203}$

Dr. Tory was chairman of an advisory committee to help establish the new faculty. The minutes show an organization meeting in the President's house on Monday, 3 October 1921. Chief Justice Harvey, Chairman of the Board of Governors, and Mr. Justice Stuart, Chancellor of the University, were present. From the University were John Weir, newly appointed professor and soon to become Dean, Professor A.F. McGoun and the Registrar Cecil Race. Representing the Law Society were Frank Ford and H.H. Parlee. Steer and William Dixon-Craig completed the Committee. It adopted the Canadian Bar Association curriculum for the first year of the course.

In the following May, Steer was present when a "Law Committee" and then the Advisory Committee confirmed the examination results for first year and settled the curriculum for the two senior years. The list of courses followed that recommended by the Canadian Bar Association. Among the courses approved were Property II and Equity I in second year and Property III and Equity II in third. Property II covered the Land Titles Act while Equity I was on the subject of Trusts. Property III embraced the law of mortgages and agreements for sale and Equity II dealt with the rules of equity excluding trusts. Steer taught them all from the beginning. Each was a heavy course, with a long and comprehensive case list. Generally Steer gave his lectures in the morning - not at the usual

200. S.A. 1907 c. 20 s. 32.

201. S.A. 1910 c. 7 s. $40(2)$.

202. See Johns, $A$ History of the Faculty of Law (1977) at 4, 5.

203. S.A. 1921 c. 5 s. 7. 
starting hour of $8: 30$ but at 8:00. He did not ask many questions or encourage lengthy debate. However, he pounded home the principle of a case with lucidity and emphasis. He never injected himself into the lectures. He expounded the decisions in cases which he himself had argued and without any reference to himself.

He became a close friend of Dean Weir. When Weir died in June of 1942, Steer helped in the reorganization of the Faculty. Dr. Malcolm MacIntyre, who succeeded Weir as Dean, went on sabbatical leave in 1944-45, and Steer was made Acting Dean. There was no one left in the full-time Faculty.

At the same time, enrolment had declined so that in 1945 the graduating class had three students. Nevertheless it was necessary to keep the doors open. Steer had the responsibility for recruiting part-time instructors in larger numbers than ever before. In the late summer of 1945 , the Faculty was faced with the prospect of veterans coming in substantial numbers. Dr. MacIntyre found himself unable to return. It was in these circumstances that Steer and Dr. Newton, President of the University, and Mr. Justice Parlee, Chairman of the Board of Governors, made an arrangement whereby the writer would come for a year to lecture full-time. ${ }^{204}$ Steer remained as Acting Dean until the spring of 1947. His heavy professional commitments induced him with great reluctance to give up his courses one by one and he had handed over all of them to others by the end of the 1947-48 session. Soon after he was made Honorary Professor. He continued to attend meetings of the Law Faculty Council until the end of 1963, and generally to retain his interest in the Faculty. When the new Law Centre at the University was formally opened on May 4, 1972, Steer attended the ceremony with Mrs. Steer, difficult though it was for him to move about.

His concern in legal education extended beyond the Faculty of Law. He felt strongly that the profession had an obligation to train graduates through providing them with articles. Over a thirty year period fifteen students (by the writer's count) were articled to him. ${ }^{205} \mathrm{~A}$ number more, articled to other members of his firm, came under his exacting tutelage.

In 1946 and the two following years he was Chairman of the Legal Education Section of the Canadian Bar Association. At the 1946 meeting at Winnipeg the association approved the steps taken to establish the Viscount Bennett Scholarships, which in subsequent years have provided for a good number of graduate students a year of graduate study. The same meeting approved establishment of a committee "to report on what, in their view is the most desirable curriculum for Canadian law schools". ${ }^{206}$

204. Steer's "loan" of the writer's services to the University became permanent.

205. Unless shown otherwise, address is Edmonton. (1931-32) The Honourable Carlton W. Clement, retired from the Court of A ppeal, January, 1982; (1932-33) Wilbur F. Bowker, Q.C., retired; (1934-35) H. Lyle Jestley, address unknown (these articles were actually served in British Columbia under a special arrangement): (1935-36) Richard G. Johnson, retired. Toronto; (1936-37) John G. MeIntosh, Victoria B.C., died 1964; (1937-38) Frank P. Layton, Q.C., died 1968; (1938-39) George L. Crawford, Q.C.. Calgary; (1939-40) Marjorie Bowker (née Montgomery) Juvenile \& Family Court Judge: (1940-41) Colonel John P. Dewis, Ottawa; (1941-42) Dr. Alexander Smith, Q.C., retired, Victoria, B.C.; (1941-42) Michel Dubuc, Clerk of Court and Sheriff, died 1959; (1943-44) Thaddeus Ives, Q.C., Lethbridge; (1947-48) David C.L. Jones, retired, Calgary; (1951-52) Mr. Justice Cameron Steer, Supreme Court, Trial Division, died 1979; (1962-63) Murray Dale.

206. 1946 Proc. C.B.A. $68,174$. 
Prior to the 1947 meeting at Ottawa, Steer prepared a statement on legal education which he hoped would receive acceptance. The annual proceedings merely reported progress on the matter of curriculum. ${ }^{207}$ The writer's clear recollection is that there was objection to the report Steer had prepared on the ground that it was too radical. The report appeared in the form of an article in the Canadian Bar Review. ${ }^{208}$

Having been a Bencher of the Law Society of Alberta in the period 1934-45 and President in his last year as a Bencher, Steer became President of the Conference of Governing Bodies (now the Federation of Law Societies) in 1947. At the meeting that year Steer reported on a number of questions - some now forgotten, some now answered and some still current. The items were public relations, automatic membership in the Association, an indemnity fund to protect clients (which only Alberta and Manitoba then had), retirement of Superior Court Judges at 75, control of appointment of King's Counsel, an All-Canada series of law reports and uniform standards of admission. ${ }^{209}$ On this last item, Dean Vincent McDonald of Dalhousie University was appointed Chairman of a committee to try to establish uniform standards of admission between the common law provinces. ${ }^{210}$

\section{CONCLUSION}

The writer has described George Hobson Steer's career as it appears in the law reports and as the writer recalls it. Not all of his cases reached the law reports. The writer has omitted a number of interesting cases because no documentation was available. ${ }^{211}$ There were also miscellaneous minor cases. Even as late as the mid-nineteen thirties he took some small debt cases and appeared in Magistrates' Court to defend a person charged with speeding, or assault, or criminal negligence, or procuring an abortion. He prepared these defenses, presented the evidence and cross-examined with the same care which he brought to bear in a Supreme Court case.

It will be apparent from this account that Steer was dedicated to his profession. Were a student to mutter against heavy assignments the rejoinder was clear, "If you expect to practise law you must be prepared to work!" At the same time Steer did appreciate good performance and was in many ways helpful to young practitioners though one would never know it from him. Indeed had he been loquacious or given to moralizing or reminiscing it would have been easier to paint a picture. Peculiarly a private man, he kept personal matters and his thoughts and beliefs to himself.

Without the degree of Bachelor of Laws, he received an honorary degree of Doctor of Laws from Queen's University and also from the University of Alberta. On 25 June, 1971 he was appointed to the Order of

207. 1947 Proc. C.B.A. 30.

208. Steer, "On Legal Education in Canada" (1947) 25 Can Bar Rev. 943.

209. 1947 Proc. C.B.A. 132.

210. The Committee made its final report in 1951: see 1951 Proc. C.B.A. 115.

211. The same is true of a federal commission or inquiry of which Steer was a member around the end of World War II. The writer's recollection is that it had to do with the grain trade in Saskatchewan. Then there was an inquiry into the collapse of a span of the Second Narrows Bridge at Vancouver after World War II. The writer is not clear as to Steer's role. 
Canada and the investiture was made by Lieutenant Governor Grant MacEwan at Steer's home on November 7, 1972.

One might wonder why Steer never became a judge. It is commonly understood that twice he had the refusal of an appointment to the Supreme Court of Canada.

At the funeral in Robertson-Wesley Church in June, 1975 the Rev. Dr. Edworthy read Chapter IV of Paul's Second Epistle to Timothy: "I have fought a good fight, I have finished my course, I have kept the faith." 